\title{
An extensive study of bromination of cis,trans,trans-1,5,9- cyclododecatriene: product structures and conformations
}

\author{
Keith Smith, ${ }^{* a}$ Chia-Hui Liu, ${ }^{a}$ Gamal A. El-Hiti, $\dagger^{a}$ and in part Gurvinder S. Kang, ${ }^{a}$ \\ Elfyn Jones, ${ }^{a}$ Simon G. Clement, ${ }^{a}$ Alex D. Checquer, ${ }^{a}$ Oliver W. Howarth, ${ }^{b}$ \\ Michael B. Hursthouse $\stackrel{+}{c}^{c}$ and Simon J. Coles $\stackrel{\leftarrow}{c}^{c}$ \\ a Centre for Clean Chemistry, Department of Chemistry, University of Wales Swansea, \\ Singleton Park, Swansea, UK SA2 8PP \\ ${ }^{b}$ Department of Chemistry, University of Warwick, Coventry, UK CV4 $7 A L$ \\ ${ }^{c}$ Department of Chemistry, University of Wales Cardiff, Cardiff, UK CF1 3TB
}

Received 11th November 2004, Accepted 23rd March 2005

First published as an Advance Article on the web 14th April 2005

Bromine has been added to cis,trans,trans-1,5,9-cyclododecatriene under various reaction conditions. All expected direct addition products have been isolated, and their structures have been determined by microanalysis, NMR and X-ray crystallography. Advanced NMR techniques were used to determine solution conformations of several of the compounds, enabling comparison with the solid-state conformations obtained by crystallography.

\section{Introduction}

$1,2,5,6,9,10$-Hexabromocyclododecane $(\mathrm{HBCD})$ is a commercially important bromine-containing cycloaliphatic flame retardant containing $74.7 \%$ bromine. $^{1}$ This important material is suitable for incorporation into various plastics, especially expanded polystyrene resins, and is also used in textiles, adhesives and coatings. ${ }^{1-3}$ In general, HBCD is manufactured by the bromination of cis,trans,trans-1,5,9-cyclododecatriene (CDT). Simple anti-addition of $\mathrm{Br}_{2}$ across each of the three double bonds can lead to a mixture of three diastereoisomers: HBCD-1, HBCD-2 and HBCD-3 (Scheme 1). In practice, the commercial material has a melting range that varies typically from 172 $184^{\circ} \mathrm{C}$ for a crude product to $201-205^{\circ} \mathrm{C}$ for the highest-melting version following crystallisation. The melting range of $\mathrm{HBCD}$ is important for its use as a flame retardant for technical reasons associated with the blending process. ${ }^{4,5}$ It is therefore highly desirable to develop methods for the selective synthesis of the high-melting isomer.

Although the commercial procedures in use do lead to a significant predominance of the high-melting isomer, ${ }^{6}$ relatively few academic studies of the processes or products have been carried out. In the preliminary stages of this study we showed that the structure of the high-melting isomer (HBCD- $\gamma, 207-209^{\circ} \mathrm{C}$ ) is identical to HBCD-1 in Scheme $1 .^{7}$ Also HBCD- $\beta$ and HBCD$\alpha$ have been shown to be identical to HBCD-2 and HBCD-3. ${ }^{7}$ However, little is known about any of the intermediates in the process and even less about the factors that influence the course of the reaction. It was felt that an understanding of the structures and solution conformations of the intermediates and products might help in the design of more suitable processes for synthesis of specific products. The aim of this study was therefore to isolate and characterise all nine products shown in Scheme 1, to study their solution and solid phase conformations, and to gain insight into the processes interconnecting them. We also provide details of the preliminary work.

\section{Results and discussion}

At the outset of the work only the major component of the commercial product (i.e. HBCD-1) was easily available in pure

$\dagger$ Permanent address: Department of Chemistry, Faculty of Science, Tanta University, Tanta 31527, Egypt.

$\$$ Current address: Department of Chemistry, Southampton University, Southampton, UK SO17 1BJ.

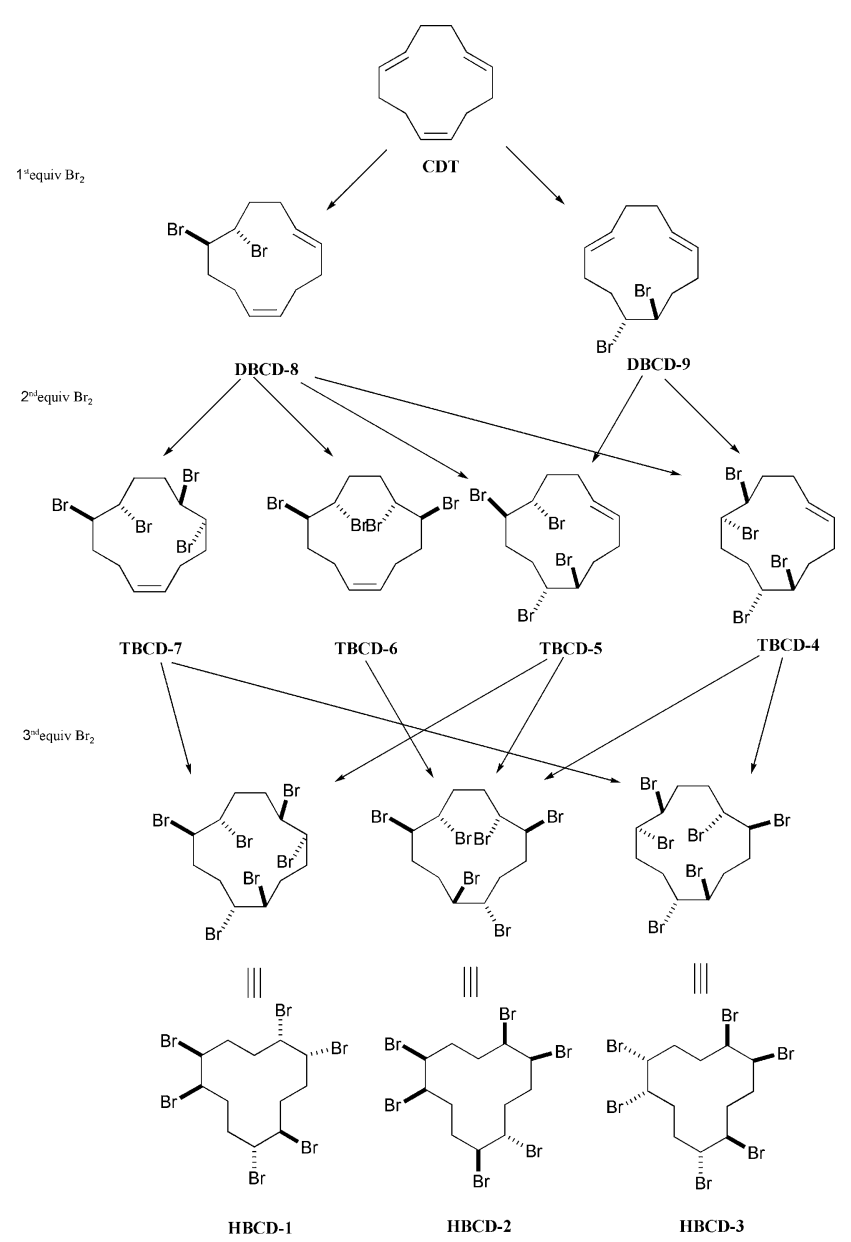

Scheme 1 Possible products resulting from sequential anti-addition of bromine to the double bonds of cis,trans,trans-1,5,9-cyclododecatriene (CDT). The prefixes refer to dibromocyclododecadienes (DBCD), tetrabromocyclododecenes (TBCD) and hexabromocyclododecanes (HBCD).

form, following recrystallisation. In order to monitor reactions, HPLC was used and conditions were found (Spherisorb ODS2 or Zorbax ODS, acetonitrile-water $89: 11,1 \mathrm{~cm}^{3} \mathrm{~min}^{-1}$ ) which allowed separation of most of the compounds observed. Initially, it was possible to record only the peak areas of components 
relative to that of the HBCD-1 peak. Subsequently, however, when other products had been isolated and characterised, it became possible to determine relative response factors for those components. The relative peak areas previously recorded could then be converted into actual proportions of products. Proportions determined in this way are recorded throughout this work unless otherwise indicated. A response factor equal to that of HBCD-1 was assumed for calculation of the proportion of all unknown products.

\section{Addition of three equivalents of $\mathrm{Br}_{2}$ to CDT}

The synthesis of HBCD by addition of three molar equivalents of $\mathrm{Br}_{2}$ to CDT has been studied before. ${ }^{89}$ The mechanism of addition of bromine to alkenes has been long established and involves anti-addition via a cyclic bromonium ion. ${ }^{10-13}$ This leads to the three potential products HBCD-1, HBCD-2, and HBCD-3. Indeed, the commercial materials generally contain three products, termed $\alpha, \beta$ and $\gamma$. Furthermore, commercial processes for the synthesis of HBCD typically involve the use of a solvent mixture containing polar and non-polar components. It was felt that variations in the proportions of such solvents might have a significant influence on the conformations of the various reaction components, which might lead in consequence to differences in the product proportions. Therefore, in our initial work we prepared solutions of bromine in a variety of solvent mixtures, estimated the bromine concentration by iodometric titration, and added a small excess of such a solution to a solution of CDT in the same solvent. After reaction the solvent was removed entirely and an aliquot of the solid obtained was analysed by HPLC. The reaction was carried out using a large variety of solvents, temperatures and concentrations, the results of a few of which are given in Table 1.

As indicated in Table 1, over a wide range of conditions the amount of HBCD-3 was never very great. No conditions could be found which gave this isomer in sufficient quantity to allow its isolation by a technique (like crystallisation) that could be used on a manufacturing scale. By contrast, under appropriate conditions either HBCD-1 or HBCD-2 could be produced in a yield of over $80 \%$, thereby confirming the importance of the solvent composition on the outcome of the reaction. In the case of HBCD-1, it was possible to isolate the pure product in $85 \%$ yield by simple washing of the best crude product with ethanol. Pure HBCD-2 could be obtained by repeated recrystallisation of the appropriate crude product, although an alternative method was achieved by bromination of a TBCD isomer (see later). Meanwhile, in order to provide a sample of pure HBCD-3, the thermal rearrangement of HBCD-1 was investigated.

\section{Synthesis of HBCD-3 by thermal rearrangement of HBCD-1}

In previous work it has been reported that at $190{ }^{\circ} \mathrm{C}$ HBCD1 rearranges to yield a mixture of HBCD-3 (78\%), HBCD-2 $(13 \%)$ and HBCD-1 $(9 \%) .{ }^{14}$ It is evident that HBCD-3 must be the thermodynamically more stable isomer. It is believed that the intermediate transition state involves a cyclic bromonium ion. $^{15-18}$

A reaction was carried out under conditions similar to those reported in the literature, with similar results. After washing and treatment with activated charcoal pure HBCD-3 was obtained in $74 \%$ yield. With conditions established for preparation of pure samples of any of the three HBCD isomers, attention was turned to the production of tetrabromocyclododecenes (TBCD).

\section{Addition of two equivalents of $\mathrm{Br}_{2}$ to CDT}

The synthesis of TBCD isomers by addition of two molar equivalents of $\mathrm{Br}_{2}$ to $\mathrm{CDT}$ was attempted under conditions similar to those used in the synthesis of HBCD. The results of selected experiments are shown in Table 2.

As can be seen from Table 2, only two of the four isomeric TBCDs are formed in significant quantities under any of the conditions tried. The proportions of the two isomers, later shown to be TBCD-5 and TBCD-7, could be varied greatly merely by changing the amount of ethanol in a dichloromethaneethanol solvent mixture. With very little ethanol and at low temperature the reaction produced almost entirely TBCD-5,

Table 1 Use of various solvents for reaction of CDT with three equivalents of bromine ${ }^{a}$

\begin{tabular}{|c|c|c|c|c|c|}
\hline \multirow[b]{2}{*}{ Solvent (ratio) } & \multicolumn{5}{|c|}{ Product proportions $(\%)$} \\
\hline & HBCD-1 & HBCD-2 & HBCD-3 & TBCD-5 & Unknown $^{b}$ \\
\hline $\mathrm{EtOH}-\mathrm{CH}_{2} \mathrm{Cl}_{2}(60: 40)^{c}$ & 91 & 8 & 0 & 1 & 0 \\
\hline EtOH$-\mathrm{CH}_{2} \mathrm{Cl}_{2}(5: 95)$ & 44 & 45 & 11 & 0 & 0 \\
\hline EtOH$-\mathrm{CH}_{2} \mathrm{Cl}_{2}(1: 99)$ & 39 & 50 & 11 & 0 & 0 \\
\hline $\mathrm{EtOH}-\mathrm{CHCl}_{3}(1: 99)$ & 33 & 56 & 11 & 0 & 0 \\
\hline $\mathrm{MeCN}-\mathrm{CH}_{2} \mathrm{Cl}_{2}$ (1: 99) & 14 & 80 & 13 & 0 & 0 \\
\hline$n-\mathrm{PrOH}-\mathrm{CH}_{2} \mathrm{Cl}_{2}(1: 99)$ & 26 & 61 & 11 & 0 & 2 \\
\hline
\end{tabular}

${ }^{a}$ The bromine solution added was at $20^{\circ} \mathrm{C}$ and the alkene solution at $2{ }^{\circ} \mathrm{C}$; both the $\mathrm{Br}_{2}$ and $\mathrm{CDT}$ solutions were $c a$. $0.5 \mathrm{M}$. ${ }^{b} \mathrm{~A}$ response factor equal to that of HBCD-1 was assumed for calculation of the proportion of this unknown. ${ }^{c}$ Triene solution at $-78^{\circ} \mathrm{C}$.

Table 2 Use of various solvents and temperatures for reactions of CDT with two equivalents of bromine ${ }^{a}$

\begin{tabular}{|c|c|c|c|c|c|}
\hline \multirow[b]{2}{*}{ Temp. $/{ }^{\circ} \mathrm{C}$} & \multirow[b]{2}{*}{ Solvent (ratio) } & \multicolumn{4}{|c|}{ Product proportions $(\%)$} \\
\hline & & TBCD-5 & TBCD-7 & DBCD-8 & Others $^{b}$ \\
\hline-78 & $\mathrm{EtOH}-\mathrm{CH}_{2} \mathrm{Cl}_{2}(3: 97)$ & 82 & 17 & 1 & 0 \\
\hline-78 & $\mathrm{EtOH}-\mathrm{CH}_{2} \mathrm{Cl}_{2}(5: 95)$ & 67 & 26 & 7 & 0 \\
\hline 18 & $\mathrm{EtOH}-\mathrm{CH}_{2} \mathrm{Cl}_{2}(80: 20)$ & 0 & 85 & 7 & 8 \\
\hline 0 & $\mathrm{EtOH}-\mathrm{CH}_{2} \mathrm{Cl}_{2}(80: 20)$ & 4 & 73 & 11 & 12 \\
\hline-78 & $n$-PrOH$-\mathrm{CH}_{2} \mathrm{Cl}_{2}(3: 97)$ & 83 & 17 & 0 & 0 \\
\hline-78 & $n$-PrOH$-\mathrm{CH}_{2} \mathrm{Cl}_{2}(5: 95)$ & 74 & 20 & 1 & 5 \\
\hline
\end{tabular}

${ }^{a}$ The concentration of both solutions was $c a .0 .5 \mathrm{M}$. During the addition the bromine solution was at $18-19{ }^{\circ} \mathrm{C} .{ }^{b}$ Assuming a response factor equivalent to that of HBCD-1. 
and this product could be isolated pure in $80 \%$ yield following washing with ethanol and recrystallisation. In $80 \%$ ethanol$\mathrm{CH}_{2} \mathrm{Cl}_{2}$ at ambient temperature the major component was TBCD-7 (85\%). A large scale reaction carried out at low temperature gave a crude product which was washed with ethanol and recrystallised to give pure TBCD-7 in $48 \%$ isolated yield.

If the proposed mechanism of isomerisation of the HBCD isomers at high temperature ${ }^{14-18}$ is correct, it should be possible to isomerise TBCD-5 into TBCD-4 (eqn. (1)) and TBCD-7 into TBCD-6 (eqn. (2)) via the corresponding bromonium ions. Attention was therefore turned to these possibilities.<smiles>Br/C=C\CCC(Br)[C@H](Br)CCC(Br)Br</smiles>

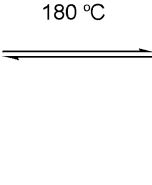

TBCD-5 Thermal isomerisation of TBCD-5

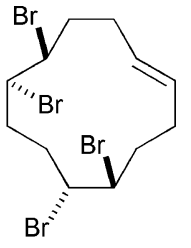

TBCD-4
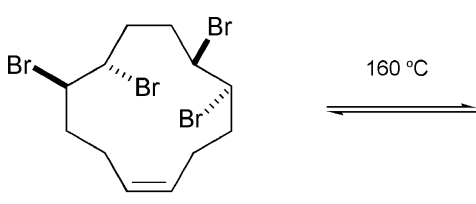

TBCD-7

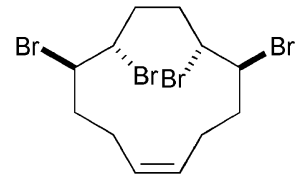

TBCD-6
Thermal isomerisation of TBCD-7

\section{Synthesis of TBCD-4 by thermal isomerisation of TBCD-5}

Thermal rearrangement of TBCD-5 was investigated by heating this compound at elevated temperatures similar to those used for the thermal rearrangement of HBCD-1. The optimum temperature appeared to be about $180{ }^{\circ} \mathrm{C}$, and a time study was therefore conducted at this temperature. Table 3 shows the results.

Several features emerge from the results in Table 3. A period of $1-1.5 \mathrm{~h}$ at $180{ }^{\circ} \mathrm{C}$ is sufficient to establish the equilibrium mixture of TBCD-4 and TBCD-5, and TBCD-4 (ca. 76\%) predominates over TBCD-5 ( $\mathrm{ca} .24 \%$ ) by a factor of about 3 in that mixture. With prolonged heating some kind of autocatalysed decomposition seems to take place, since a rapid weight loss ensues and a range of additional, mostly unidentified peaks appears in the HPLC trace.

A preparative-scale reaction was carried out for $1 \mathrm{~h}$ at $180^{\circ} \mathrm{C}$ and a mixture rich in TBCD-4 was obtained, as described

Table 3 Experimental results for thermal rearrangement of TBCD-5 at $180{ }^{\circ} \mathrm{C}$ for various reaction times

\begin{tabular}{lllll}
\hline & & \multicolumn{3}{l}{ Product proportions (\%) } \\
\cline { 4 - 5 } Time/min & Weight loss (\%) & TBCD-4 & TBCD-5 & Unknown $^{a}$ \\
\hline 45 & 0.8 & 69 & 31 & 0 \\
60 & 1.2 & 73 & 27 & 0 \\
75 & 4.4 & 77 & 23 & 0 \\
90 & 6.5 & 76 & 24 & 0 \\
105 & 47.7 & 71 & 21 & 8 \\
120 & 54.6 & Many products & & \\
& & obtained & &
\end{tabular}

${ }^{a}$ A response factor equal to that of $\mathrm{HBCD}-1$ was assumed for this unknown. above. The product was washed and repeatedly recrystallised, because the two isomers are not easily separated by a single crystallisation. Eventually, pure TBCD-4 was obtained in an isolated yield of $21 \%$.

\section{Synthesis of TBCD-6 by thermal isomerisation of TBCD-7}

The thermal rearrangement of TBCD-7 was attempted at various temperatures and the optimum appeared to be about $160{ }^{\circ} \mathrm{C}$. A time study was conducted at this temperature and the results are given in Table 4.

The results in Table 4 reveal that the equilibrium mixture contains almost equal amounts of TBCD-6 and TBCD-7, and is established after about 40 minutes at $160^{\circ} \mathrm{C}$. Prolonged heating beyond about 100 minutes causes autocatalysed decomposition, resulting in substantial weight loss and the production of a more diverse product mixture.

Following a larger scale reaction carried out under the optimum conditions the crude product was subjected to repeated washing, partial extraction and recrystallisation processes until a sample of pure TBCD-6 was obtained in 15\% isolated yield.

At this point pure samples of all four TBCD isomers were available in reasonable quantity. It was therefore possible to undertake studies of the addition of bromine to these compounds. Such studies would help in confirmation of the structures of the TBCD isomers because of the pattern of HBCD isomers produced (Scheme 1) and might lead to more efficient means of producing specific $\mathrm{HBCD}$ isomers.

\section{Addition of one equivalent of $\mathrm{Br}_{2}$ to TBCD-4}

Addition of one equivalent of bromine to TBCD-4 gave a mixture of HBCD-3 and HBCD-2 in a ratio of $c a .50: 50$. Various solvent mixtures, such as ethanol-dichloromethane $(60: 40$ to 1 : 99) and dichloromethane-acetonitrile (90:10 to $10: 90)$, gave very little change in the proportion of the isomers. Therefore, further bromination of TBCD-4 is not a useful procedure for selective formation of any particular HBCD isomer.

\section{Addition of one equivalent of $\mathrm{Br}_{2}$ to TBCD-5}

Addition of one equivalent of bromine to TBCD-5 produced a mixture of HBCD-2 and HBCD-1 under a variety of conditions and in various solvent mixtures. Table 5 shows a selection of the results obtained.

The results in Table 5 reveal that the proportions of the two products depend greatly on the nature of the solvent. In the presence of a significant amount of a polar solvent the major component is HBCD-1. Solubility problems sometimes prevented study of conditions involving a very ethanol-rich solvent, but optimum production of HBCD-1 appeared to occur in a solvent mixture comprising $c a .40 \%$ ethanol and $60 \%$ of a

Table 4 Experimental results for thermal rearrangement of TBCD-7 at $160^{\circ} \mathrm{C}$ for various reaction times

\begin{tabular}{lllll}
\hline & & \multicolumn{3}{c}{ Product proportions $(\%)$} \\
\cline { 3 - 5 } Time/min & Weight loss (\%) & TBCD-6 & TBCD-7 & Unknowns $^{a}$ \\
\hline \multirow{2}{*}{10} & 0 & 23 & 63 & 14 \\
15 & 0.7 & 36 & 64 & 0 \\
20 & 0 & 38 & 56 & 6 \\
40 & 0.1 & 47 & 49 & 5 \\
45 & 1.4 & 45 & 44 & 8 \\
60 & 0.9 & 49 & 47 & 4 \\
75 & 4.0 & 48 & 48 & 4 \\
90 & 0.8 & 49 & 48 & 3 \\
105 & 4.6 & 43 & 40 & 17 \\
120 & 39.3 & 41 & 37 & 22
\end{tabular}

${ }^{a}$ A response factor equal to that of HBCD-1 was assumed for the unknowns. 
Table 5 Reaction of TBCD-5 with one equivalent of bromine

\begin{tabular}{|c|c|c|c|c|}
\hline \multirow[b]{2}{*}{ Temp. $/{ }^{\circ} \mathrm{C}^{a}$} & \multirow[b]{2}{*}{ Solvent (ratio) } & \multicolumn{3}{|c|}{ Product proportions $(\%)$} \\
\hline & & HBCD-1 & HBCD-2 & Others $^{b}$ \\
\hline 2 & $\mathrm{EtOH}-\mathrm{CH}_{2} \mathrm{Cl}_{2}(60: 40)$ & 86 & 14 & 0 \\
\hline 2 & EtOH- $\mathrm{CH}_{2} \mathrm{Cl}_{2}(40: 60)$ & 89 & 11 & 0 \\
\hline 2 & $\mathrm{EtOH}-\mathrm{CH}_{2} \mathrm{Cl}_{2}(10: 90)$ & 70 & 30 & 0 \\
\hline 2 & EtOH- $\mathrm{CH}_{2} \mathrm{Cl}_{2}(5: 95)$ & 45 & 55 & 0 \\
\hline 2 & EtOH- $-\mathrm{CH}_{2} \mathrm{Cl}_{2}(1: 99)$ & 23 & 77 & 0 \\
\hline 2 & $n-\mathrm{PrOH}-\mathrm{CH}_{2} \mathrm{Cl}_{2}(60: 40)$ & 78 & 22 & 0 \\
\hline 2 & $n-\mathrm{PrOH}-\mathrm{CH}_{2} \mathrm{Cl}_{2}(40: 60)$ & 76 & 23 & 0 \\
\hline 2 & $n-\mathrm{PrOH}-\mathrm{CH}_{2} \mathrm{Cl}_{2}(10: 90)$ & 53 & 46 & 0 \\
\hline 2 & $n-\mathrm{PrOH}-\mathrm{CH}_{2} \mathrm{Cl}_{2}(5: 95)$ & 38 & 62 & 0 \\
\hline 2 & $n-\mathrm{PrOH}-\mathrm{CH}_{2} \mathrm{Cl}_{2}(3: 97)$ & 25 & 75 & 0 \\
\hline 2 & $n$-PrOH- $\mathrm{CH}_{2} \mathrm{Cl}_{2}(1: 99)$ & 10 & 90 & 0 \\
\hline 40 & $\mathrm{EtOH}-\mathrm{CHCl}_{3}(90: 10)$ & 68 & 25 & 7 \\
\hline 40 & EtOH-CHCl $3(20: 80)$ & 65 & 35 & 0 \\
\hline 40 & EtOH-CHCl $3(5: 95)$ & 28 & 69 & 3 \\
\hline 40 & EtOH-CHCl $3(1: 99)$ & 11 & 80 & 9 \\
\hline 35 & EtOH-dioxane $(60: 40)$ & 82 & 18 & 0 \\
\hline 35 & EtOH-dioxane $(40: 60)$ & 87 & 13 & 0 \\
\hline 35 & EtOH-dioxane $(10: 90)$ & 61 & 39 & 0 \\
\hline 35 & EtOH-1,2-dichloroethane $(30: 70)$ & 77 & 23 & 0 \\
\hline 35 & EtOH-1,2-dichlorobenzene $(70: 30)$ & 75 & 25 & 0 \\
\hline 50 & EtOH-cyclopentane $(60: 40)$ & 85 & 15 & 0 \\
\hline 35 & EtOH-chlorobenzene $(30: 70)$ & 73 & 27 & 0 \\
\hline 2 & $\mathrm{MeCN}-\mathrm{CH}_{2} \mathrm{Cl}_{2}(5: 95)$ & 6 & 91 & 3 \\
\hline 2 & $\mathrm{MeCN}-\mathrm{CH}_{2} \mathrm{Cl}_{2}(1: 99)$ & 3 & 94 & 3 \\
\hline
\end{tabular}

${ }^{a}$ The bromine solution added was at $20{ }^{\circ} \mathrm{C}$ in all cases; the temperature refers to the reaction vessel. ${ }^{b}$ Assuming a response factor equivalent to that of HBCD-1.

non-polar solvent. Under such conditions the proportion of HBCD-1 produced could be as high as $89 \%$.

When the solvent contained very little of the polar component the major product was HBCD-2. The proportion of this component reached $94 \%$ in $\mathrm{MeCN}-\mathrm{CH}_{2} \mathrm{Cl}_{2}=1: 99$. The small amount of polar solvent is useful, because without it the product mixture becomes messy and more deeply coloured. Since a low concentration of polar solvent favours the production of TBCD-5 from CDT and also favours conversion of TBCD-5 into HBCD-2, there is little advantage in carrying out the stepwise reaction sequence if HBCD-2 is the desired product.

In principle, use of conditions for reaction of CDT with bromine that favour TBCD-5 production, then replacement of the solvent by one favouring HBCD-1 production for addition of the final equivalent of bromine, could be used for selective production of HBCD-1. However, the yield of HBCD-1 obtained in such a reaction sequence was not significantly better than that obtained using the optimum solvent for the single step process from CDT and three equivalents of bromine.

\section{Addition of one equivalent of $\mathrm{Br}_{2}$ to TBCD-6}

Addition of one equivalent of bromine to TBCD-6 should produce HBCD-2 only (Scheme 1). Indeed, a reaction carried out in 1-propanol-dichloromethane (60:40) gave almost 100\% of HBCD-2. Unfortunately, the relative difficulty of obtaining TBCD-6 means that this route to HBCD-2 is not as attractive as the less selective but more direct synthesis of this compound from CDT and three equivalents of bromine.

\section{Addition of one equivalent of $\mathrm{Br}_{2}$ to TBCD-7}

Addition of one equivalent of bromine to TBCD-7 produced a mixture of HBCD-1 and HBCD-3. The reaction was conducted in a variety of solvent mixtures, the results of a selection of which are recorded in Table 6 .

The results in Table 6 demonstrate that the addition of bromine to TBCD-7 gives mainly HBCD-1 under a whole range of conditions. Although the reaction can be used for selective synthesis of HBCD-1, it cannot be used for selective synthesis of
HBCD-3. Since the conditions for selective synthesis of TBCD7 are also appropriate for its conversion into HBCD-1, there is little advantage in carrying out the reaction stepwise via TBCD-7.

At this point it was appropriate to investigate the production and reaction of the dibromocyclododecadiene isomers, DBCD8 and DBCD-9. Therefore, the addition of one equivalent of bromine to CDT was studied.

\section{Addition of one equivalent of $\mathrm{Br}_{2}$ to CDT}

One equivalent of bromine was added to CDT under various conditions involving variation of temperature and solvent, but the reaction led to a single DBCD isomer, DBCD-8, under all conditions tried. In ethanol-dichloromethane (60:40) DBCD8 was obtained in $85-91 \%$ yield with minimum production of TBCD isomers or residual CDT. Pure DBCD-8 could be isolated in $74 \%$ yield following washing and recrystallisation.

Clearly, the reaction of bromine with CDT could not be used to provide a sample of DBCD-9. Also, since isomerisation processes such as those used for interconverting TBCD-5 and TBCD-4 involve a common bromonium ion intermediate, DBCD-9 cannot be produced by isomerisation of DBCD-8. Therefore, an alternative approach was necessary. It was hoped that partial debromination of TBCD-5 might produce a mixture containing sufficient DBCD-9 to allow its isolation. Reaction of TBCD-5 with zinc was therefore attempted.

\section{Debromination of TBCD-5 for synthesis of DBCD-9}

Previous studies have shown that the debromination of vicinal dibromides by metals such as magnesium and zinc involves exclusively trans elimination of bromine. ${ }^{19-26}$ Therefore, a sample of TBCD-5 was dissolved in hot ethanol and added to one equivalent of zinc powder. The mixture was allowed to cool and stirred for two days. The product was shown by HPLC to be a mixture of several components but did contain the product later shown to be DBCD-9. The mixture was extracted into pentane and evaporated to give an oil, which was dissolved in ethanol and allowed to crystallise to give pure DBCD-9 in about $6 \%$ 
Table 6 Reaction of TBCD-7 with one equivalent of bromine

\begin{tabular}{|c|c|c|c|c|c|}
\hline \multirow[b]{2}{*}{ Temp. $\left({ }^{\circ} \mathrm{C}\right)^{a}$} & \multirow[b]{2}{*}{ Solvent (ratio) } & \multicolumn{4}{|c|}{ Product proportions $(\%)$} \\
\hline & & HBCD-1 & HBCD-3 & TBCD-7 & Others $^{b}$ \\
\hline 2 & $\mathrm{EtOH}-\mathrm{CH}_{2} \mathrm{Cl}_{2}(70: 30)$ & 83 & 17 & 0 & 0 \\
\hline 2 & $\mathrm{EtOH}-\mathrm{CH}_{2} \mathrm{Cl}_{2}(60: 40)$ & 90 & 10 & 0 & 0 \\
\hline 2 & $\mathrm{EtOH}-\mathrm{CH}_{2} \mathrm{Cl}_{2}(40: 60)$ & 92 & 8 & 0 & 0 \\
\hline 2 & EtOH$-\mathrm{CH}_{2} \mathrm{Cl}_{2}(30: 70)$ & 88 & 12 & 0 & 0 \\
\hline 2 & $n-\mathrm{PrOH}-\mathrm{CH}_{2} \mathrm{Cl}_{2}(70: 30)$ & 85 & 13 & 2 & 0 \\
\hline 2 & $n-\mathrm{PrOH}-\mathrm{CH}_{2} \mathrm{Cl}_{2}(30: 70)$ & 84 & 16 & 0 & 0 \\
\hline 2 & $\mathrm{CHCl}_{3}-\mathrm{CH}_{2} \mathrm{Cl}_{2}(40: 60)$ & 64 & 19 & 9 & 8 \\
\hline 2 & $\mathrm{CHCl}_{3}-\mathrm{CH}_{2} \mathrm{Cl}_{2}(20: 80)$ & 41 & 43 & 8 & 8 \\
\hline 2 & $\mathrm{MeCN}-\mathrm{CH}_{2} \mathrm{Cl}_{2}(90: 10)$ & 77 & 23 & 0 & 0 \\
\hline 40 & $\mathrm{EtOH}-\mathrm{CHCl}_{3}(70: 30)$ & 87 & 13 & 0 & 0 \\
\hline 40 & $\mathrm{EtOH}-\mathrm{CHCl}_{3}(30: 70)$ & 70 & 13 & 11 & 0 \\
\hline 40 & EtOH-cyclopentane $(60: 40)$ & 82 & 18 & 0 & 0 \\
\hline 40 & EtOH-cyclopentane $(30: 70)$ & 87 & 13 & 0 & 0 \\
\hline 35 & EtOH-dioxane $(90: 10)$ & 80 & 20 & 0 & 0 \\
\hline 35 & EtOH-dioxane $(10: 90)$ & 78 & 22 & 0 & 0 \\
\hline 35 & EtOH-1,2-dichlorobenzene $(90: 10)$ & 93 & 7 & 0 & 0 \\
\hline 35 & EtOH-1,2-dichlorobenzene $(10: 90)$ & 73 & 27 & 0 & 0 \\
\hline 20 & EtOH-MeCN $(70: 30)$ & 78 & 16 & 0 & 0 \\
\hline 20 & EtOH-MeCN $(30: 70)$ & 78 & 16 & 0 & 0 \\
\hline 35 & EtOH-1,2-dichloroethane $(70: 30)$ & 79 & 21 & 0 & 0 \\
\hline 20 & EtOH-chlorobenzene $(70: 30)$ & 69 & 31 & 0 & 0 \\
\hline 20 & EtOH-chlorobenzene $(30: 70)$ & 83 & 17 & 0 & 0 \\
\hline 20 & $\mathrm{EtOH}-\mathrm{CHCl}_{3}(70: 30)$ & 73 & 27 & 0 & 0 \\
\hline
\end{tabular}

${ }^{a}$ The bromine solution added was at $20{ }^{\circ} \mathrm{C}$ in all cases; the temperature refers to the reaction vessel. ${ }^{b}$ Assuming a response factor equivalent to that of HBCD-1.

yield. Although the recovery was poor, this process provided enough of the product for studies of its structure and reactions. Attention was then turned to the reactions of the DBCD isomers with one equivalent of bromine.

\section{Addition of one equivalent of $\mathrm{Br}_{2}$ to $\mathrm{DBCD}-8$}

One equivalent of bromine was added to DBCD-8 under various conditions. In principle, it should be possible to produce all four isomers of TBCD by this approach (see Scheme 1). However, the reaction led to TBCD-5 and TBCD-7 with little evidence for TBCD-4 or TBCD-6 under all conditions tried (Table 7).

The results in Table 7 indicate that it is possible to produce TBCD-5 cleanly in a solvent comprising dichloromethanechloroform (20:80). By use of $\mathrm{CH}_{2} \mathrm{Cl}_{2}$-ethanol mixtures it is possible to increase the proportion of TBCD-7 substantially, and in ethanol- $\mathrm{CH}_{2} \mathrm{Cl}_{2}(20: 80)$ at $-78{ }^{\circ} \mathrm{C}$ for $1 \mathrm{~h}$ then overnight at room temperature it is formed in $76 \%$ yield, thus explaining the high yield of TBCD-7 from CDT and two equivalents of bromine under such conditions (Table 2).

\section{Addition of one equivalent of $\mathrm{Br}_{2}$ to DBCD-9}

Addition of one equivalent of bromine to DBCD-9 under a variety of conditions gave rise to both TBCD-4 and TBCD-5, and also to several by-products. Therefore, further bromination of DBCD-9 does not appear to be a useful procedure for selective formation of any particular TBCD isomer, especially since DBCD-9 is itself difficult to obtain.

Table 7 Reaction of DBCD-8 with one equivalent of bromine in different solvents at various temperatures

\begin{tabular}{|c|c|c|c|c|c|}
\hline \multirow{2}{*}{$\begin{array}{l}\text { Temp. } /{ }^{\circ} \mathrm{C}^{a} \\
\text { Temp. } /{ }^{\circ} \mathrm{C}^{a}\end{array}$} & \multirow{2}{*}{$\begin{array}{l}\text { Solvent (ratio) } \\
\text { Solvent (ratio) }\end{array}$} & \multicolumn{4}{|c|}{ Product proportions ( $\%)$} \\
\hline & & TBCD-5 & TBCD-7 & DBCD-8 & Others $^{b}$ \\
\hline-78 & EtOH$-\mathrm{CH}_{2} \mathrm{Cl}_{2}(90: 10)$ & 25 & 63 & 12 & 0 \\
\hline 0 & $\mathrm{EtOH}-\mathrm{CH}_{2} \mathrm{Cl}_{2}(90: 10)$ & 33 & 61 & 6 & 0 \\
\hline 19 & $\mathrm{EtOH}-\mathrm{CH}_{2} \mathrm{Cl}_{2}(90: 10)$ & 37 & 49 & 14 & 0 \\
\hline-78 & $\mathrm{EtOH}-\mathrm{CH}_{2} \mathrm{Cl}_{2}(80: 20)$ & 53 & 45 & 2 & 0 \\
\hline 0 & $\mathrm{EtOH}-\mathrm{CH}_{2} \mathrm{Cl}_{2}(80: 20)$ & 45 & 51 & 4 & 0 \\
\hline 19 & $\mathrm{EtOH}-\mathrm{CH}_{2} \mathrm{Cl}_{2}(80: 20)$ & 36 & 62 & 2 & 0 \\
\hline-78 & $\mathrm{EtOH}-\mathrm{CH}_{2} \mathrm{Cl}_{2}(60: 40)$ & 19 & 74 & 7 & 0 \\
\hline 0 & $\mathrm{EtOH}-\mathrm{CH}_{2} \mathrm{Cl}_{2}(60: 40)$ & 32 & 66 & 2 & 0 \\
\hline 19 & $\mathrm{EtOH}-\mathrm{CH}_{2} \mathrm{Cl}_{2}(60: 40)$ & 35 & 60 & 5 & 0 \\
\hline-78 & $\mathrm{EtOH}-\mathrm{CH}_{2} \mathrm{Cl}_{2}(20: 80)$ & 18 & 76 & 6 & 0 \\
\hline 0 & $\mathrm{EtOH}-\mathrm{CH}_{2} \mathrm{Cl}_{2}(20: 80)$ & 21 & 73 & 6 & 0 \\
\hline 19 & $\mathrm{EtOH}-\mathrm{CH}_{2} \mathrm{Cl}_{2}(20: 80)$ & 31 & 59 & 10 & 0 \\
\hline-78 & $\mathrm{EtOH}-\mathrm{CH}_{2} \mathrm{Cl}_{2}(10: 90)$ & 41 & 58 & 1 & 0 \\
\hline 0 & $\mathrm{EtOH}-\mathrm{CH}_{2} \mathrm{Cl}_{2}(10: 90)$ & 38 & 59 & 3 & 0 \\
\hline 19 & $\mathrm{EtOH}-\mathrm{CH}_{2} \mathrm{Cl}_{2}(10: 90)$ & 50 & 45 & 5 & 0 \\
\hline-78 & EtOH-cyclopentane $(90: 10)$ & 68 & 30 & 2 & 0 \\
\hline-78 & EtOH-cyclopentane $(40: 60)$ & 66 & 27 & 7 & 0 \\
\hline-78 & $\mathrm{CHCl}_{3}-\mathrm{CH}_{2} \mathrm{Cl}_{2}(80: 20)$ & 90 & 0 & 0 & 10 \\
\hline-78 & $\mathrm{CHCl}_{3}-\mathrm{CH}_{2} \mathrm{Cl}_{2}(60: 40)$ & 64 & 0 & 0 & 26 \\
\hline
\end{tabular}

${ }^{a}$ The bromine solution added was at $20{ }^{\circ} \mathrm{C}$ in all cases; the temperature refers to the reaction vessel. ${ }^{b} \mathbf{H B C D}-1$ and $\mathbf{H B C D}-2$. 
At this point the study of the syntheses and interconversions of all nine compounds listed in Scheme 1 was complete. Scheme 2 summarises the approaches developed here for the syntheses of these compounds. Detailed procedures are given in the experimental section for the favoured route to each compound.

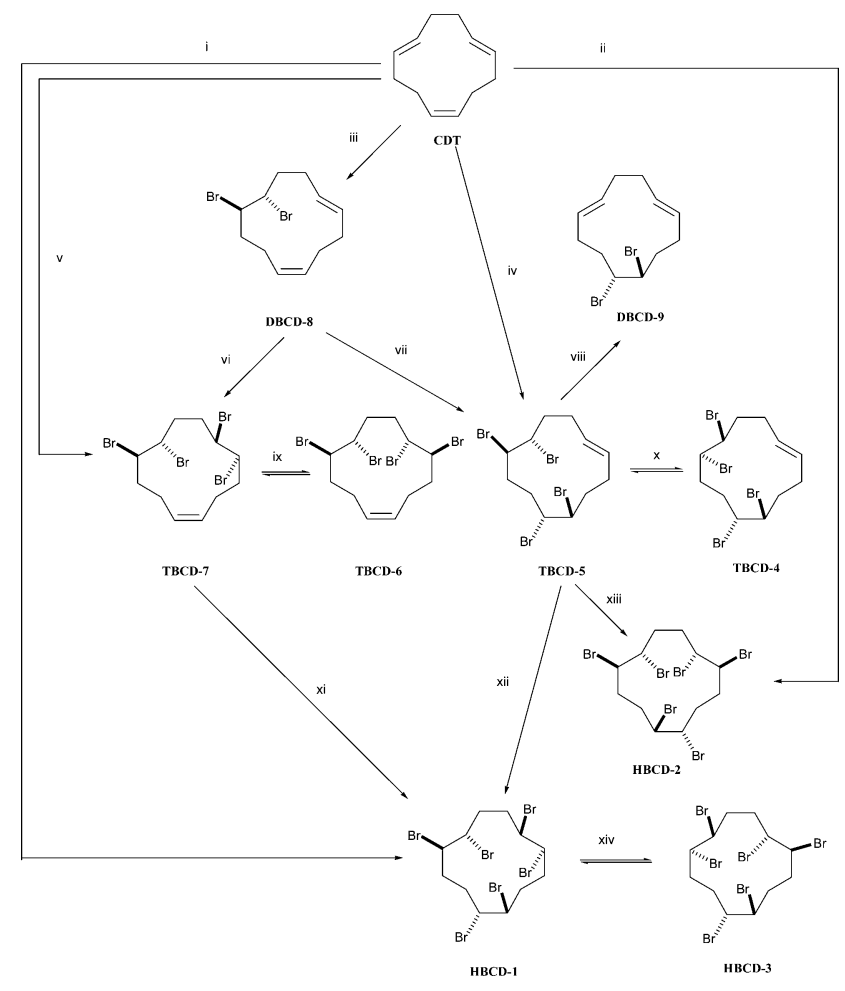

Scheme 2 Procedures for preparation of bromination products of CDT Reagents and conditions: i) $3 \mathrm{Br}_{2}, \mathrm{EtOH}-\mathrm{CH}_{2} \mathrm{Cl}_{2}(60: 40),-78{ }^{\circ} \mathrm{C}$; ii) $3 \mathrm{Br}_{2}, \mathrm{MeCN}-\mathrm{CH}_{2} \mathrm{Cl}_{2}(1: 99), 2{ }^{\circ} \mathrm{C}$; iii) $\mathrm{Br}_{2}, \mathrm{EtOH}-\mathrm{CH}_{2} \mathrm{Cl}_{2}(60: 40)$, $-78^{\circ} \mathrm{C}$; iv) $\left.2 \mathrm{Br}_{2}, \mathrm{EtOH}-\mathrm{CH}_{2} \mathrm{Cl}_{2}(1: 99),-78^{\circ} \mathrm{C} ; \mathrm{v}\right) 2 \mathrm{Br}_{2}, \mathrm{EtOH}-\mathrm{CH}_{2} \mathrm{Cl}_{2}$ (80:20), $18{ }^{\circ} \mathrm{C}$; vi) $\mathrm{Br}_{2}$, EtOH- $\mathrm{CH}_{2} \mathrm{Cl}_{2}(80: 20), 20{ }^{\circ} \mathrm{C}$; vii) $\mathrm{Br}_{2}$, $\mathrm{MeCN}-\mathrm{CH}_{2} \mathrm{Cl}_{2}(1: 99), 2^{\circ} \mathrm{C}$; viii) $\mathrm{Zn}, \mathrm{EtOH}, 90^{\circ} \rightarrow 20{ }^{\circ} \mathrm{C}$; ix) $160^{\circ} \mathrm{C}$; x) $180^{\circ} \mathrm{C}$; xi) $\mathrm{Br}_{2}$, EtOH- $\mathrm{CH}_{2} \mathrm{Cl}_{2}(40: 60), 2^{\circ} \mathrm{C}$; xii) $\mathrm{Br}_{2}, \mathrm{EtOH}-\mathrm{CH}_{2} \mathrm{Cl}_{2}$ (40:60), $2{ }^{\circ} \mathrm{C}$; xiii) $\mathrm{Br}_{2}, \mathrm{MeCN} \mathrm{CH}_{2} \mathrm{Cl}_{2}(1: 99), 2{ }^{\circ} \mathrm{C}$; xiv) $190{ }^{\circ} \mathrm{C}$.

Thus far the identity of each product has been recorded as if known, but many of the products have never previously been characterised. Characterisation was carried out by Xray crystallography, NMR spectroscopy and by correlation of interconnecting structures as indicated in Tables 1-7, in addition to microanalysis and mass spectrometry.

\section{X-Ray crystallography of products}

Crystals of all compounds produced in this study were subjected to X-ray crystallographic analysis, but it proved impossible to obtain a structure from DBCD-9. The results for the others confirmed the gross structures of the compounds and also revealed their solid-state conformations. Fig. 1 shows drawings of the structures determined, and Table 8 gives the crystal data and structure refinement information. The CCDC reference numbers are as follows: HBCD-1: 261488; HBCD-2: 217888; HBCD-3: 261191; TBCD-4: 217896; TBCD-5: 261487; TBCD-6: 217898; TBCD-7: 217897; DBCD-8: 260841. See http://www.rsc.org/suppdata/ob/b4/b417156j/ for crystallographic data in CIF or other electronic format.

\section{NMR spectroscopy}

NMR spectroscopy was used with the intention not only of providing confirmation of the gross structures of the compounds described here, but also of providing insight into their solution conformations. However, relatively little information about

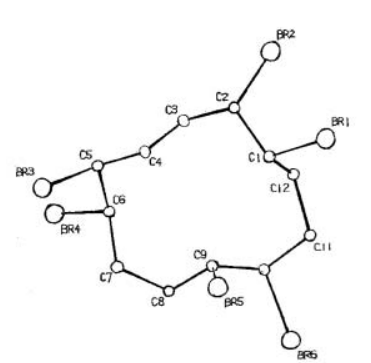

HBCD-1
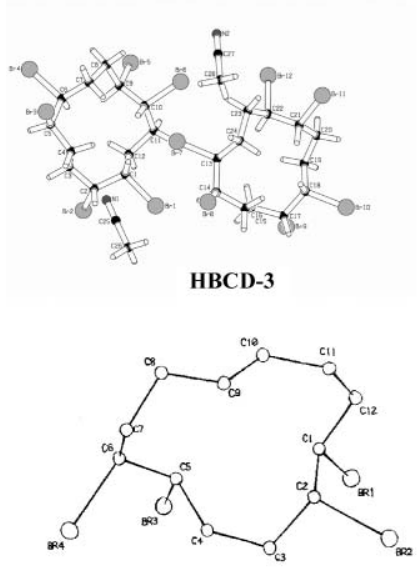

TBCD-5

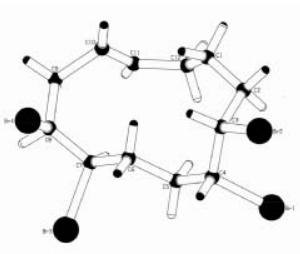

TBCD-7

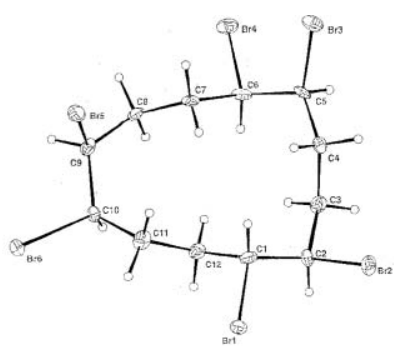

HBCD-2

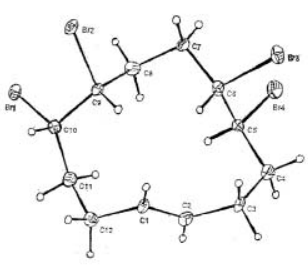

TBCD-4

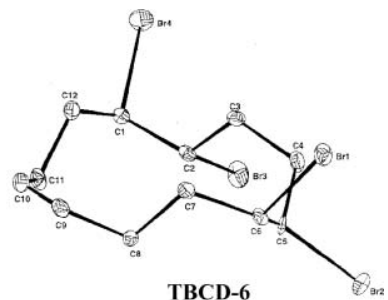

TBCD-6

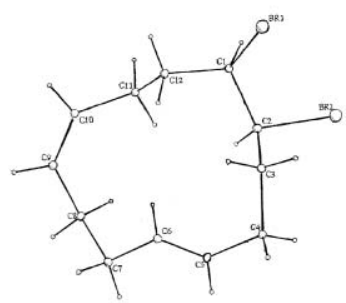

DBCD-8
Fig. 1 X-Ray structures of the 8 compounds determined. Note that for HBCD-3 there were two different molecules in the unit cell, along with two molecules of acetonitrile.

the NMR properties of such compounds is available in the literature. ${ }^{7,27}$ Therefore, the NMR properties of the various compounds were investigated using a combination of simple ${ }^{1} \mathrm{H}$ and ${ }^{13} \mathrm{C}$ measurements, solvent shifts, NOE and variable temperature measurements, and $2 \mathrm{D}$ spectra $(\mathrm{H}-\mathrm{H}$ COSY and $\mathrm{C}-\mathrm{H}$ COSY).

(a) HBCD-1. The structure of HBCD-1 was verified by measurement of its NMR spectra at various temperatures and with the help of solvent-induced shifts. HBCD-1 has a $\mathrm{C}_{2}$ axis of symmetry. Therefore, the ${ }^{1} \mathrm{H}$ NMR spectrum should show nine signals. By addition of $\mathrm{d}_{8}$-toluene to a $\mathrm{CDCl}_{3}$ solution of HBCD-1, a best mixture was found $\left(\mathrm{CDCl}_{3}-\mathrm{d}_{8}\right.$-toluene $\left.45: 55\right)$ which showed all nine signals (labelled a-i) individually. There were also signals due to other conformations, which were largely eliminated at $-50{ }^{\circ} \mathrm{C}$ (Fig. 2). Further information was derived from the $\mathrm{C}-\mathrm{H}$ COSY spectrum (Fig. 3). The ${ }^{13} \mathrm{C}$ and ${ }^{1} \mathrm{H}$ shifts of the nuclei bonded to one another showed up clearly in the contour plot. For example, the protons with shifts at $1.85 \mathrm{ppm}$ $\left(\mathrm{H}_{\mathrm{d}}\right)$ and $1.36 \mathrm{ppm}\left(\mathrm{H}_{\mathrm{g}}\right)$ are bonded to the $\mathrm{C}$ atom at $35.4 \mathrm{ppm}$, and all other protons could be similarly assigned to specific carbon atoms. The H-H COSY spectrum (Fig. 4 and Table 9) allowed all proton connectivities to be established. For example, the proton $\mathrm{H}_{\mathrm{i}}$ was found as a coupling partner of the proton $\mathrm{H}_{\mathrm{a}}$. Therefore, it became possible to deduce the sequence of atoms 


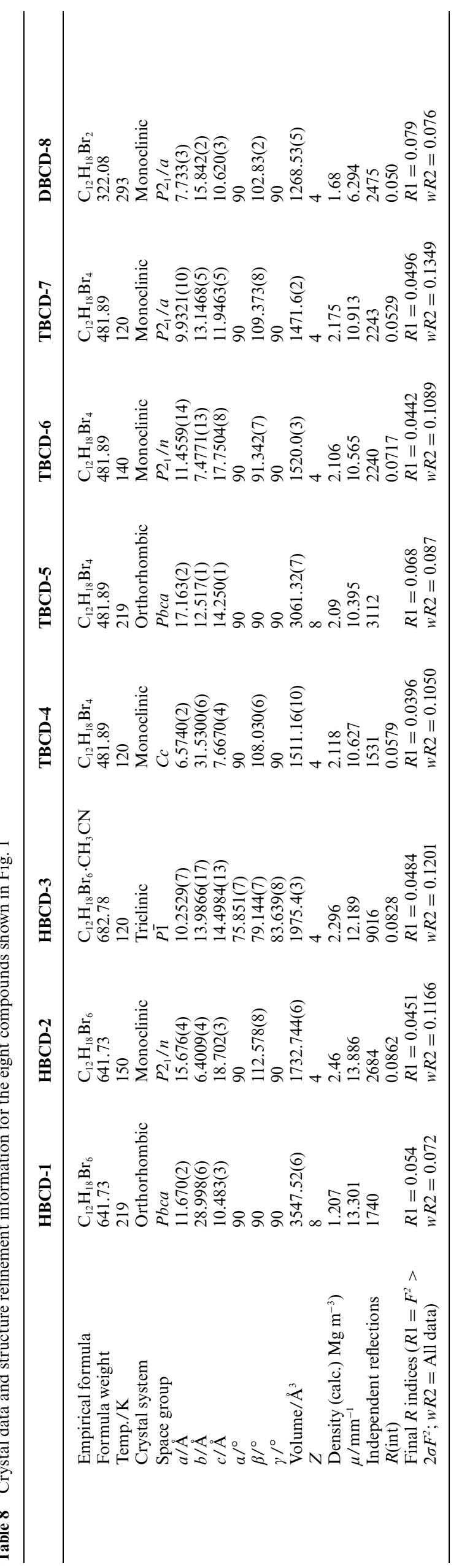

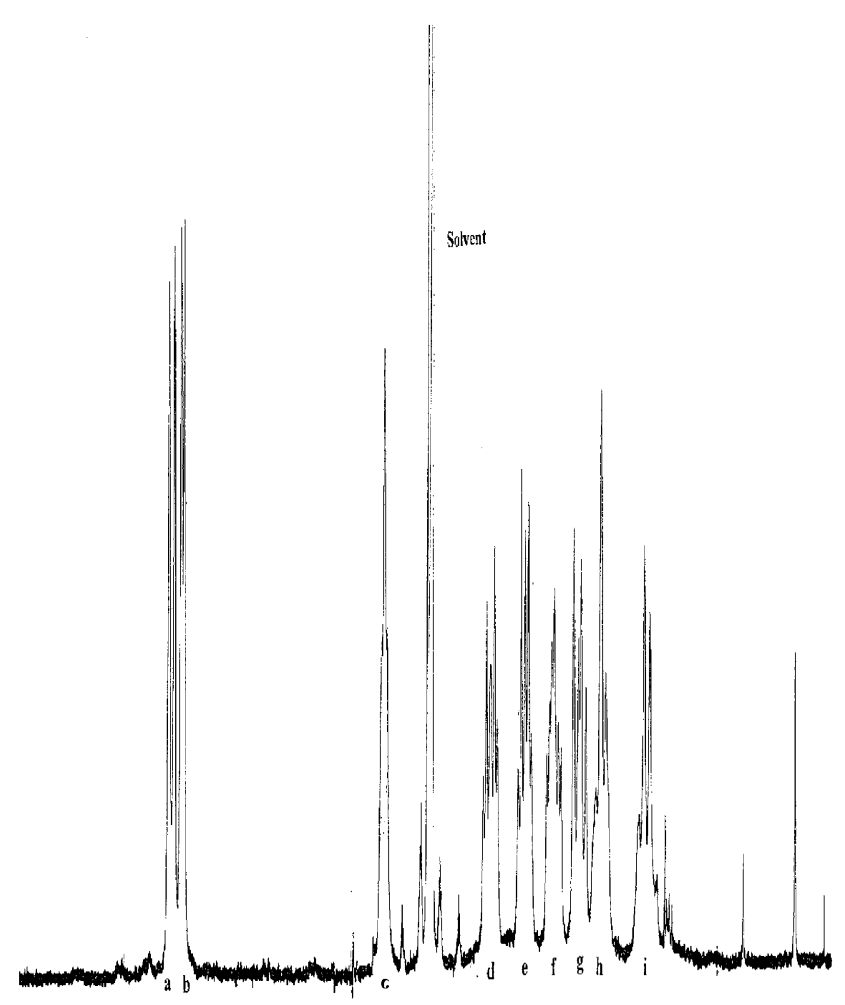

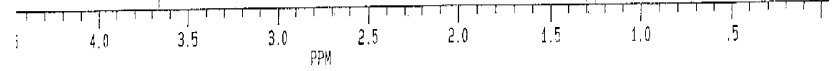

Fig. $2400 \mathrm{MHz}^{1} \mathrm{H}$ NMR spectrum of $\mathbf{H B C D}-1$ in $\mathrm{CDCl}_{3}-\mathrm{d}_{8}$-toluene $(45: 55)$ at $-50^{\circ} \mathrm{C}$.

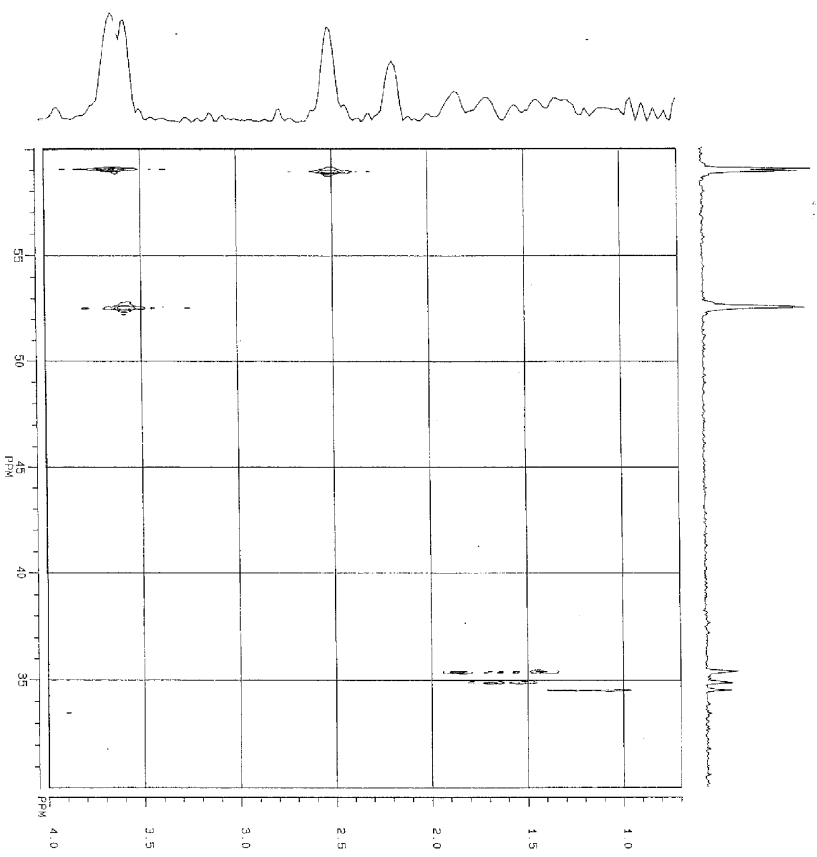

Fig. $3 \mathrm{C}-\mathrm{H}$ COSY spectrum of HBCD-1 in $\mathrm{CDCl}_{3}-\mathrm{d}_{8}$-toluene (45 : 55) at $-50{ }^{\circ} \mathrm{C}$.

around the ring. Proton $\mathrm{H}_{\mathrm{c}}$ was identified as that associated with the $\mathrm{CHBr}$ groups of the trans-dibromo unit by the lack of any coupling with either of the other $\mathrm{CHBr}$ protons, $\mathrm{H}_{\mathrm{a}}$ and $\mathrm{H}_{\mathrm{b}}$. This enabled the construction of a fully assigned structure (Fig. 5).

By reference to the normal spectrum, $\mathrm{H}_{\mathrm{a}}$ and $\mathrm{H}_{\mathrm{i}}$ could be identified as having the common coupling constant ${ }^{3} J_{\text {ai }}=$ $12 \mathrm{~Hz}$. Similarly $\mathrm{H}_{\mathrm{i}}$ and $\mathrm{H}_{\mathrm{h}}, \mathrm{H}_{\mathrm{i}^{\prime}}$ and $\mathrm{H}_{\mathrm{h}^{\prime}}$ could be seen to have ${ }^{2} J_{\text {ih }}={ }^{3} J_{\text {ih' }}=12 \mathrm{~Hz}$. Protons $\mathrm{H}_{\mathrm{b}}$ and $\mathrm{H}_{\mathrm{g}}$ couple to $\mathrm{H}_{\mathrm{d}}$ with a vicinal coupling constant ${ }^{3} J_{\mathrm{bd}}=7 \mathrm{~Hz}$ and a geminal coupling 


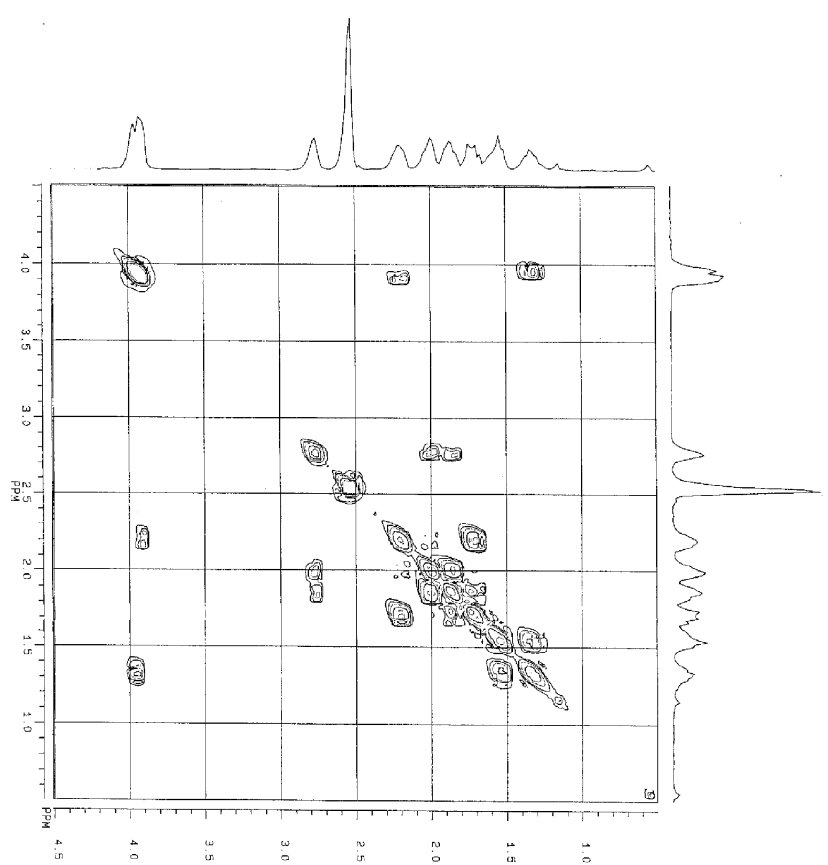

Fig. $4 \mathrm{H}-\mathrm{H}$ COSY spectrum of HBCD-1 in $\mathrm{CDCl}_{3}-\mathrm{d}_{8}$-toluene (45 : 55) at $-50^{\circ} \mathrm{C}$

${ }^{2} J_{\mathrm{dg}}=16 \mathrm{~Hz}$. Proton $\mathrm{H}_{\mathrm{g}}$ shows a further coupling to $\mathrm{H}_{\mathrm{f}}$, with vicinal coupling ${ }^{3} J_{\mathrm{gf}}=11 \mathrm{~Hz}$. The following additional coupling constants can also be identified: ${ }^{3} J_{\mathrm{cf}}=6 \mathrm{~Hz},{ }^{3} J_{\mathrm{ce}}=6 \mathrm{~Hz},{ }^{3} J_{\mathrm{de}}=$ $7 \mathrm{~Hz}$ and ${ }^{2} J_{\text {ef }}=15 \mathrm{~Hz}$ (Table 9). From the vicinal HH coupling constants the dihedral angles between vicinal hydrogens could be assessed.

The NOE difference spectra (Table 10) provided yet more detailed information regarding the structure. Particularly significant were the long-range NOE effects seen between protons $\mathrm{H}_{\mathrm{b}}, \mathrm{H}_{\mathrm{c}}, \mathrm{H}_{\mathrm{g}}$ and $\mathrm{H}_{\mathrm{i}}$, which indicated the spatial proximity of these protons. When all of the NOEs, connectivities and $\mathrm{H}-$ $\mathrm{H}$ coupling constants were considered together, a space-filling model could be constructed which satisfied all of the data. The model showed, for example, that this conformation of HBCD1 places $\mathrm{H}_{\mathrm{a}}$ and $\mathrm{H}_{\mathrm{i}}$ at a dihedral angle of $c a$. $180^{\circ}$ whilst $\mathrm{H}_{\mathrm{a}}$ and $\mathrm{H}_{\mathrm{h}}$ have a dihedral angle of $c a .90^{\circ}$, so that no coupling is detected. The similarity of the coupling constants $J_{\text {ce }}$ and $J_{\text {cf }}$ likewise indicates that the $\mathrm{C}-\mathrm{H}_{\mathrm{c}}$ bond approximately bisects the $\mathrm{H}_{\mathrm{e}}-\mathrm{C}-\mathrm{H}_{\mathrm{f}}$ angle.

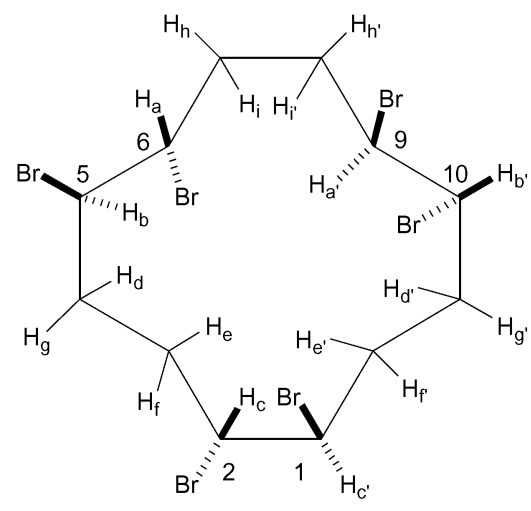

Fig. 5 Assigned structure for HBCD-1.

The conformational structure is shown in Fig. 6. This structure of HBCD-1 was found to be very similar to the X-ray crystal structure., ${ }^{4,7 b}$ Therefore, it seems that the major solution conformation and the solid-state conformation are almost identical.

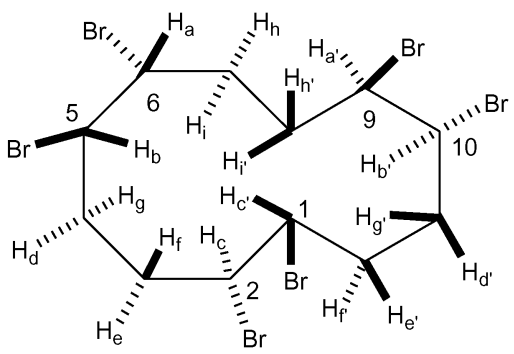

Fig. 6 Conformational structure of HBCD-1 as determined by NMR.

(b) HBCD-2. HBCD-2 has no $\mathrm{C}_{2}$ axis of symmetry. The ${ }^{1} \mathrm{H}$ NMR spectrum should therefore show eighteen signals. At $-50{ }^{\circ} \mathrm{C}$ the spectum showed only one major conformation. Mixtures of solvents were found $\left(\mathrm{CDCl}_{3}-\mathrm{d}_{8}\right.$-toluene $10: 90$ and $90: 10)$ which showed twelve or thirteen separate signals. Furthermore, C-H COSY spectra in the two mixtures allowed the identification of all geminal pairs of hydrogens. The $\mathrm{H}-$ $\mathrm{H}$ COSY spectra allowed connectivities to be established. Therefore, a structure showing the locations of all carbon atoms and attached hydrogens could be drawn (Fig. 7). Unfortunately, NOE difference spectra were not very clear, and it was difficult to get estimates of coupling constants for a number of protons

Table 9 Interpretation of $\mathrm{H}-\mathrm{H} / \mathrm{C}-\mathrm{H}$ COSY and $\mathrm{H}-\mathrm{H}$ coupling assignments of $\mathbf{H B C D}-\mathbf{1}$ recorded in $\mathrm{CDCl}_{3}-\mathrm{d}_{8}$-toluene $(45: 55)$ at $-50^{\circ} \mathrm{C}$

\begin{tabular}{lllll}
\hline$\delta_{\mathrm{C}} / \mathrm{ppm}$ & Associated proton(s) & $\delta_{\mathrm{H}} / \mathrm{ppm}$ & $\mathrm{H}-\mathrm{H}$ multiplicities & $J / \mathrm{Hz}$ \\
\hline 59.0 & $\mathrm{H}_{\mathrm{a}}$ & 3.61 & $\mathrm{~d}$ & $J_{\mathrm{ai}}=12$ \\
52.5 & $\mathrm{H}_{\mathrm{b}}$ & 3.55 & $\mathrm{~d}$ & $J_{\mathrm{bd}}=7$ \\
58.9 & $\mathrm{H}_{\mathrm{c}}$ & 2.43 & $\mathrm{t}$ & $J_{\mathrm{ce}}=6, J_{\mathrm{cf}}=6$ \\
35.4 & $\mathrm{H}_{\mathrm{d}}, \mathrm{H}_{\mathrm{g}}$ & $1.85,1.36$ & $\mathrm{dt}, \mathrm{dd}$ & $J_{\mathrm{de}}=7, J_{\mathrm{db}}=7, J_{\mathrm{dg}}=16, J_{\mathrm{gf}}=11$ \\
34.9 & $\mathrm{H}_{\mathrm{e}}, \mathrm{H}_{\mathrm{f}}$ & $1.66,1.50$ & $\mathrm{~m}, \mathrm{~m}$ & $J_{\text {ec }}=6, J_{\text {ed }}=7, J_{\mathrm{ef}}=15, J_{\mathrm{fc}}=6, J_{\mathrm{fg}}=11$ \\
34.5 & $\mathrm{H}_{\mathrm{h}}, \mathrm{H}_{\mathrm{i}}$ & $1.23,0.99$ & $\mathrm{t}, \mathrm{q}$ & $J_{\text {ia }}=12, J_{\mathrm{ih}}=12, J_{\text {ih' }}=12$ \\
\hline
\end{tabular}

Table 10 Interpretation of the NOE difference spectra for $\mathbf{H B C D}-\mathbf{1}$ in $\mathrm{CDCl}_{3}-\mathrm{d}_{8}$-toluene $(45: 55)$ at $-50{ }^{\circ} \mathrm{C}$

\begin{tabular}{llll}
\hline Proton & Irradiation/ppm & Protons exhibiting NOE & NOE increase (\%) \\
\hline $\mathrm{H}_{\mathrm{a}}$ & 3.61 & $\mathrm{c}, \mathrm{h}, \mathrm{i}$ & $1.2,4.1,1.7$ \\
$\mathrm{H}_{\mathrm{b}}$ & 3.55 & $\mathrm{c}, \mathrm{f}, \mathrm{g}, \mathrm{h}, \mathrm{i}$ & $2.7,1.7,1.5,1.4,3.3$ \\
$\mathrm{H}_{\mathrm{c}}$ & 2.43 & $\mathrm{~b}, \mathrm{e}, \mathrm{f}, \mathrm{g}, \mathrm{i}$ & $8.4,3.2,3.2,1.9,1.6$ \\
$\mathrm{H}_{\mathrm{d}}$ & 1.85 & $\mathrm{~b}, \mathrm{~g}$ & $1.8,7.3$ \\
$\mathrm{H}_{\mathrm{e}}$ & 1.66 & $\mathrm{~b}, \mathrm{c}, \mathrm{f}$ & $2.5,1.8,6.1$ \\
$\mathrm{H}_{\mathrm{f}}$ & 1.50 & $\mathrm{~b}, \mathrm{c}, \mathrm{e}$ & $2.6,3.0,2.5$ \\
$\mathrm{H}_{\mathrm{g}}$ & 1.36 & $\mathrm{a} / \mathrm{b}, \mathrm{c}, \mathrm{d}$ & $2.7,3.2,6.3$ \\
$\mathrm{H}_{\mathrm{h}}$ & 1.23 & $\mathrm{a}, \mathrm{i}$ & $7.4,7.9$ \\
$\mathrm{H}_{\mathrm{i}}$ & 0.99 & $\mathrm{a} / \mathrm{b}, \mathrm{c}, \mathrm{h}$ & $10.1,4.3,4.6$ \\
\hline
\end{tabular}




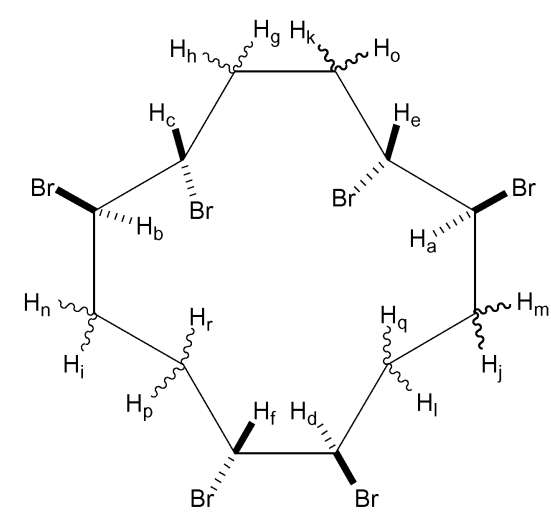

Fig. 7 Labelled structure of HBCD-2 (for explanation of the subscript letters, see experimental section)

from the simple spectra. Therefore, it was not possible to deduce a proper conformation from the spectral data provided.

(c) HBCD-3. HBCD-3 has a $\mathrm{C}_{2}$ axis of symmetry. Therefore, the ${ }^{1} \mathrm{H}$ NMR spectrum should show only nine signals. It was found that all nine protons were observed separately when the spectrum was recorded in a mixture of $\mathrm{CDCl}_{3}-\mathrm{d}_{8}$ toluene $(75: 25)$ at $-25^{\circ} \mathrm{C}$. $\mathrm{H}-\mathrm{H}$ COSY and $\mathrm{C}-\mathrm{H}$ COSY spectra allowed all connectivities to be established. Further information was derived from the NOE difference spectra and the coupling constants, which provided more detailed information about the conformation, as indicated for HBCD-1. The conformational structure deduced is shown in Fig. 8. This conformational structure was found to be very similar to the X-ray crystal structure of HBCD-3.

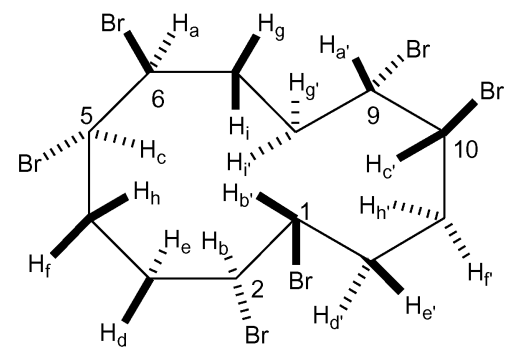

Fig. 8 Conformation of HBCD-3 (for explanation of the subscript letters, see experimental section).

(d) TBCD-4. TBCD-4 has no $\mathrm{C}_{2}$ axis of symmetry. Therefore, the ${ }^{1} \mathrm{H}$ NMR spectrum should show eighteen signals. By recording ${ }^{1} \mathrm{H}$ NMR spectra at temperatures between $50{ }^{\circ} \mathrm{C}$ and $-50{ }^{\circ} \mathrm{C}$ in $\mathrm{CDCl}_{3}$, the best temperature was found to be $25^{\circ} \mathrm{C}$, which provided an NMR spectrum with two distinct signals for $\mathrm{CH}=\mathrm{CH}$ and 4 distinct signals for $\mathrm{CHBr}$, but the 12 signals for the $\mathrm{CH}_{2}$ groups were not well separated, because of signal overcrowding in the aliphatic range between 1.8 and $2.6 \mathrm{ppm}$. These results are similar to those obtained by Matsuba et al. ${ }^{27}$

Solvent-induced shifts were also investigated by addition of $\mathrm{d}_{8}$-toluene to a $\mathrm{CDCl}_{3}$ solution of TBCD-4, but did not provide good separation. $\mathrm{H}-\mathrm{H}$ and $\mathrm{C}-\mathrm{H}$ COSY spectra could not be fully analysed. It was not possible to deduce a solution conformation.

(e) TBCD-5. TBCD-5 has no $\mathrm{C}_{2}$ axis of symmetry. Therefore, each carbon atom in the molecule is different. In order to clarify the structure of TBCD-5, ${ }^{13} \mathrm{C}$ NMR spectra were recorded at various temperatures from $50{ }^{\circ} \mathrm{C}$ to $-50{ }^{\circ} \mathrm{C}$ in $\mathrm{CDCl}_{3}$. The best temperature $\left(-50^{\circ} \mathrm{C}\right)$ showed eleven distinct and major resonance lines. Signals due to other conformations were largely eliminated at this temperature. The ${ }^{1} \mathrm{H}$ NMR spectrum should show eighteen signals, but only the low field signals were separated in $\mathrm{CDCl}_{3}$ at $-50{ }^{\circ} \mathrm{C}$. Addition of $\mathrm{d}_{8}$ toluene to a $\mathrm{CDCl}_{3}$ solution of $\mathrm{TBCD}-5$ at $-50^{\circ} \mathrm{C}$ suggested that
TBCD-5 contained a significant amount of a second conformer. The COSY spectrum was very complex and could not be fully analysed. Mixtures of $\mathrm{C}_{2} \mathrm{D}_{5} \mathrm{OD}$ and $\mathrm{CD}_{2} \mathrm{Cl}_{2}$ were also tried, but the results were similar to those with $\mathrm{CDCl}_{3}-\mathrm{d}_{8}$-toluene solvent mixtures and did not help. Therefore the NMR data were not capable of providing the conformation in solution.

(f) TBCD-6. TBCD-6 has a plane of symmetry. Therefore, the ${ }^{1} \mathrm{H}$ NMR spectrum should show nine signals. By addition of $\mathrm{d}_{8}$-toluene to a $\mathrm{CDCl}_{3}$ solution of TBCD-6, mixtures were found $\left(\mathrm{CDCl}_{3}-\mathrm{d}_{8}\right.$-toluene $50: 50$ and $\left.25: 75\right)$ at $-25^{\circ} \mathrm{C}$ which showed seven or eight separate signals. Furthermore, the pair which were not separated in the latter mixture were separated in the former mixture, even though other pairs were not. Therefore, by use of two solvent mixtures, all nine protons could be acceptably resolved. $\mathrm{C}-\mathrm{H}$ and $\mathrm{H}-\mathrm{H}$ COSY spectra allowed all connectivities to be established (Fig. 9).

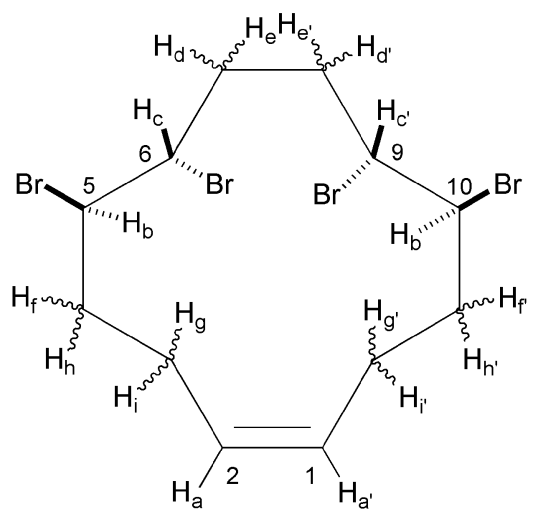

Fig. 9 Labelled structure of TBCD-6 (for explanation of the subscript letters, see experimental section).

It was hoped that information concerning the conformation of TBCD-6 in solution could be obtained by measuring coupling constants and NOE difference spectra. However, the spectra did not provide the more detailed information expected, possibly due to the presence of minor conformers or because peaks were overlapping. X-Ray diffraction methods alone were therefore used for the characterisation of TBCD-6.

(g) TBCD-7. TBCD-7 has a $\mathrm{C}_{2}$ axis of symmetry. The NMR spectra of its $\mathrm{CDCl}_{3}$ solutions show that it is a mixture of conformers between $0{ }^{\circ} \mathrm{C}$ and $-50{ }^{\circ} \mathrm{C}$. Therefore, the $\mathrm{H}-\mathrm{H}$ COSY spectrum is very complex and could not be fully analysed. The conformers are in rapid equilibrium at $50{ }^{\circ} \mathrm{C}$, but the aliphatic hydrogen signals are not well separated. On addition of $\mathrm{d}_{8}$-toluene to the $\mathrm{CDCl}_{3}$ solution, the results confirmed the rapid equilibration and also showed two equivalent protons associated with the double bond and two distinct signals each corresponding to protons associated with $\mathrm{CHBr}$ groups. The signals corresponding to the six aliphatic hydrogens, however, were still not well separated. X-Ray diffraction methods were therefore used for the full characterisation of TBCD-7 and the solution conformation could not be determined.

(h) DBCD-8. DBCD-8 has no $\mathrm{C}_{2}$ axis of symmetry. Therefore, each carbon atom in the molecule is different. In order to clarify the structure of DBCD-8, ${ }^{13} \mathrm{C}$ NMR DEPT spectra were recorded at various temperatures from $50{ }^{\circ} \mathrm{C}$ to $-50{ }^{\circ} \mathrm{C}$ in $\mathrm{CDCl}_{3}$. The best temperatures $\left(-10{ }^{\circ} \mathrm{C}\right.$ to $\left.-30{ }^{\circ} \mathrm{C}\right)$ showed thirteen distinct resonance lines, one extra one appearing in the $\mathrm{CH}_{2}$ region. At other temperatures, there were also signals due to other conformations. At $50{ }^{\circ} \mathrm{C}$ the signals had coalesced but the lines were broad and not all could be seen. The ${ }^{1} \mathrm{H}$ NMR spectrum should show eighteen signals. However, even on addition of $\mathrm{d}_{8}$-toluene to a $\mathrm{CDCl}_{3}$ solution of $\mathbf{D B C D - 8}$, it was not possible to see well-separated signals because of signal overcrowding in the aliphatic and double bond regions. 
The COSY spectra were very complex and could not be fully analysed. The full structure was therefore confirmed by X-ray crystallography, and the solution conformation could not be determined.

(i) DBCD-9. DBCD-9 has a $\mathrm{C}_{2}$ axis of symmetry. At $-70{ }^{\circ} \mathrm{C}$ its ${ }^{1} \mathrm{H}$ NMR spectra were well-resolved and showed only one major conformation. Solvents were found $\left(\mathrm{CDCl}_{3}-\mathrm{d}_{8}\right.$ toluene $50: 50$ and $\mathrm{d}_{8}$-toluene) which showed seven separate signals. Furthermore, the pairs that were not separated in the latter solvent were separated in the former mixture, even though other pairs were not. Therefore, by use of two solvent mixtures, all nine protons could be acceptably resolved. $\mathrm{C}-\mathrm{H}$ and $\mathrm{H}-\mathrm{H}$ COSY spectra allowed all connectivities to be established (Fig. 10).

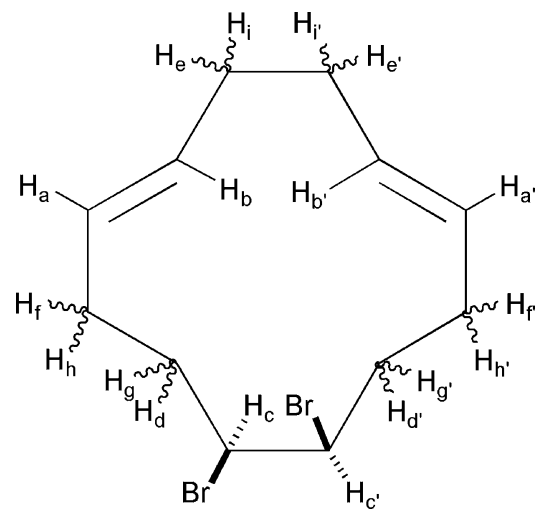

Fig. 10 Labelled structure of DBCD-9 (for explanation of the subscript letters, see experimental section).

Various NOE difference spectra (Tables 11 and 12) were recorded at $-60{ }^{\circ} \mathrm{C}$ in $\mathrm{CDCl}_{3}-\mathrm{d}_{8}$-toluene $(50: 50)$ and in $\mathrm{d}_{8}$ toluene, because at $-70{ }^{\circ} \mathrm{C}$ the $\mathrm{NOE}$ effects observed were not very clear. Although the NOEs allowed identification of closely proximate protons, it was still not possible to confirm this conformation by use of coupling constants to calculate torsional angles because some of the peaks were overlapping.

\section{Conclusion}

The bromination products HBCD-1 to HBCD-3, TBCD-4 to TBCD-7, and DBCD-8 and DBCD-9 have all been successfully synthesised, isolated and characterised. Their NMR spectra and X-ray crystallography have allowed their structures to be

Table 11 Interpretation of the NOE difference spectra of DBCD-9 in $\mathrm{CDCl}_{3}-\mathrm{d}_{8}$-toluene $(50: 50)$ at $-60{ }^{\circ} \mathrm{C}$

\begin{tabular}{lll}
\hline Proton irradiated & $\delta / \mathrm{ppm}$ & Protons exhibiting significant NOE \\
\hline $\mathrm{H}_{\mathrm{a} / \mathrm{b}}$ & 4.66 & $\mathrm{c}, \mathrm{f} / \mathrm{g}, \mathrm{i}$ \\
$\mathrm{H}_{\mathrm{c}}$ & 3.90 & $\mathrm{a} / \mathrm{b}, \mathrm{f} / \mathrm{g}, \mathrm{h}$ \\
$\mathrm{H}_{\mathrm{d}}$ & 2.20 & $\mathrm{f} / \mathrm{g}$ \\
$\mathrm{H}_{\mathrm{e}}$ & 2.03 & $\mathrm{a} / \mathrm{b}, \mathrm{i}$ \\
$\mathrm{H}_{\mathrm{f} / \mathrm{g}}$ & 1.95 & $\mathrm{a} / \mathrm{b}, \mathrm{c}, \mathrm{i}$ \\
$\mathrm{H}_{\mathrm{h}}$ & 1.83 & $\mathrm{c}$ \\
$\mathrm{H}_{\mathrm{i}}$ & 1.65 & $\mathrm{a} / \mathrm{b}, \mathrm{e}$ \\
\hline
\end{tabular}

Table 12 Interpretation of the NOE difference spectra of DBCD-9 in $\mathrm{d}_{8}$-toluene at $-60{ }^{\circ} \mathrm{C}$

\begin{tabular}{lll}
\hline Proton irradiated & $\delta / \mathrm{ppm}$ & Protons exhibiting significant NOE \\
\hline $\mathrm{H}_{\mathrm{a}}$ & 4.53 & $\mathrm{c}, \mathrm{e} / \mathrm{g}, \mathrm{f} / \mathrm{h}, \mathrm{i}$ \\
$\mathrm{H}_{\mathrm{b}}$ & 4.44 & $\mathrm{c}, \mathrm{e} / \mathrm{g}, \mathrm{f} / \mathrm{h}, \mathrm{i}$ \\
$\mathrm{H}_{\mathrm{c}}$ & 3.98 & $\mathrm{a}, \mathrm{b}, \mathrm{e} / \mathrm{g}, \mathrm{f} / \mathrm{h}$ \\
$\mathrm{H}_{\mathrm{d}}$ & 2.49 & $\mathrm{e} / \mathrm{g}, \mathrm{f} / \mathrm{h}$ \\
$\mathrm{H}_{\mathrm{e} / \mathrm{g}}$ & $2.02-2.06$ & $\mathrm{~b}, \mathrm{c}, \mathrm{d}, \mathrm{i}$ \\
$\mathrm{H}_{\mathrm{f} / \mathrm{h}}$ & 1.95 & $\mathrm{a}, \mathrm{b}, \mathrm{c}, \mathrm{d}$ \\
$\mathrm{H}_{\mathrm{i}}$ & 1.63 & $\mathrm{a}, \mathrm{b}, \mathrm{e} / \mathrm{g}$ \\
\hline
\end{tabular}

identified. For HBCD-1, HBCD-3 and DBCD-9 the NMR spectra provide evidence of the closely proximate protons (NOE) and approximate torsional angles (from coupling constants), but for DBCD-8, all TBCD isomers and HBCD-2, such evidence was not so conclusive. For the two compounds for which both solution and solid-state conformations were available, the conformations in solution were very similar to those in the solid state. If this pattern prevails for the other compounds, it may allow better understanding of the reasons for production of particular products on further bromination of such compounds.

\section{Experimental}

\section{General}

Cis,trans,trans-1,5,9-cyclododecatriene (98\%) was obtained from Aldrich or Fluka and used without further purification. Where necessary, solvents were purified by standard procedures. ${ }^{28}$ All glassware was dried in an oven at $150{ }^{\circ} \mathrm{C}$ and cooled to room temperature under a flow of nitrogen.

X-Ray analyses were obtained from the EPSRC National Crystallography Service. Elemental analyses were obtained from the laboratories of the University of Wales Cardiff. Ultra-violet spectra were recorded on a Philips PU 8720 UV/vis scanning spectrometer. Melting points were recorded on an electrothermal digital melting point apparatus and are uncorrected. Lowresolution electron impact (EI) mass spectra were obtained at $70 \mathrm{eV}$ on a VG 12/253 J mass spectrometer. Accurate mass data were obtained on a VG ZAB-E instrument. The data are presented with the molecular ion peak (the most intense one of the cluster) first, followed by several of the most abundant ion peaks with their \% relative intensity given in brackets. High performance liquid chromatography (HPLC) involved a $25 \mathrm{~cm} \times$ $4.6 \mathrm{~mm}$ column of $5 \mu$ Spherisorb ODS2 bonded phase or $5 \mu$ Zorbax ODS bonded phase. Spherisorb ODS2 separated all but two of the possible components (TBCD-4 and TBCD5), while Zorbax ODS was capable of separating these two. Mobile phase 89: 11 acetonitrile-water; flow rate $1 \mathrm{~cm}^{3} \mathrm{~min}^{-1}$; detection by UV absorption at $210 \mathrm{~nm}$; pump: LDC/Milton Roy constaMetric III; detector: LDC SpectroMONITOR III; recorder: Hewlett Packard 3390A integrator. ${ }^{1} \mathrm{H}$ and ${ }^{13} \mathrm{C}$ NMR spectra and NOE measurements were recorded on a Bruker AC 400 spectrometer at $400 \mathrm{MHz}$ for ${ }^{1} \mathrm{H}$ and $\mathrm{NOE}$ and $100 \mathrm{MHz}$ for ${ }^{13} \mathrm{C}$ measurements. The internal reference used in all spectra was tetramethylsilane. Chemical shifts $(\delta)$ are reported in parts per million (ppm), and coupling constants $J$ are in Hz. DEPT spectra were recorded using the same machine. 2D spectra were not always referenced to TMS for practical reasons, but signals could nevertheless be correlated with those in the normal NMR spectra.

\section{Typical reaction procedures}

HBCD-1 by bromination of CDT. A solution of CDT $(0.893 \mathrm{~g}, 5.50 \mathrm{mmol})$ in a mixture of ethanol $(6 \mathrm{ml})$ and dichloromethane $(4 \mathrm{ml})$ was cooled to $-78{ }^{\circ} \mathrm{C}$ in a dryice/acetone bath and vigorously stirred. Meanwhile, bromine (ca. $2.6 \mathrm{ml}$ ) was made up to a concentration of $c a .0 .50 \mathrm{M}$ in ethanol $(60 \mathrm{ml})$ and dichloromethane $(40 \mathrm{ml})$ and standardised by iodometric titration. The bromine solution $(51.0 \mathrm{ml}$, $25.5 \mathrm{mmol}$ ) was then transferred dropwise by nitrogen pressure through a plastic double-ended needle into the well-stirred CDT solution. The temperature was kept at $-78{ }^{\circ} \mathrm{C}$ during the transfer. After the addition was completed, the reaction mixture was stirred for $1 \mathrm{~h}$ at $-78{ }^{\circ} \mathrm{C}$, allowed to warm to room temperature and then stirred for a further $2 \mathrm{~h}$ to give an orange solution. The solvent was evaporated in vacuo at $40^{\circ} \mathrm{C}$, to give a crude cream-coloured solid ( $\left.3.53 \mathrm{~g}\right)$. Quantitative HPLC analysis showed the presence of HBCD-1 (91\%), HBCD$2(8 \%)$ and TBCD-5 $(1 \%)$. The crude solid was purified by washing with ethanol to give pure white solid HBCD-1 in $85 \%$ 
isolated yield. Crystallisation from a mixture of acetonitrile and dichloromethane $(60: 40)$ provided pure white crystals of HBCD-1. Mp 207-209 ${ }^{\circ} \mathrm{C}, \delta_{\mathrm{H}}\left(-50{ }^{\circ} \mathrm{C}, \mathrm{CDCl}_{3}-\mathrm{d}_{8}\right.$-toluene 45 : 55) $3.61\left(\mathrm{~d}, 2 \mathrm{H}, \mathrm{H}_{\mathrm{a}}\right), 3.55\left(\mathrm{~d}, 2 \mathrm{H}, \mathrm{H}_{\mathrm{b}}\right), 2.43\left(\mathrm{t}, 2 \mathrm{H}, \mathrm{H}_{\mathrm{c}}\right), 1.85$ $\left(\mathrm{dt}, 2 \mathrm{H}, \mathrm{H}_{\mathrm{d}}\right), 1.66\left(\mathrm{~m}, 2 \mathrm{H}, \mathrm{H}_{\mathrm{e}}\right), 1.50\left(\mathrm{~m}, 2 \mathrm{H}, \mathrm{H}_{\mathrm{f}}\right), 1.36(\mathrm{dd}$, $\left.2 \mathrm{H}, \mathrm{H}_{\mathrm{g}}\right), 1.23\left(\mathrm{t}, 2 \mathrm{H}, \mathrm{H}_{\mathrm{h}}\right)$ and $0.99\left(\mathrm{q}, 2 \mathrm{H}, \mathrm{H}_{\mathrm{i}}\right) ; \delta_{\mathrm{C}}\left(-50{ }^{\circ} \mathrm{C}\right.$, $\mathrm{CDCl}_{3}-\mathrm{d}_{8}$-toluene 45 : 55) 59.0 (C-6), 52.5 (C-5), 58.9 (C-2), 35.4 (C-4), 34.9 (C-3) and 34.5 (C-7); $m / z$ (EI) $563\left(\mathrm{M}^{+}-{ }^{79} \mathrm{Br},<1 \%\right.$ ), $561\left(\mathrm{M}^{+}-{ }^{81} \mathrm{Br},<1\right), 482\left(\mathrm{M}^{+}-{ }^{79} \mathrm{Br}-{ }^{81} \mathrm{Br},<1\right), 403(<1), 401$ (<1), 321 (2), 319 (2), 241 (4), 239 (7), 159 (26), 131 (13), 105 (28), 91 (63), 79 (100), 67 (57), 65 (38), 53 (55), 41 (74) and 39 (75) (Found: C, 22.46; H, 2.96; Br, 74.58. Calc. for $\mathrm{C}_{12} \mathrm{H}_{18} \mathrm{Br}_{6}$ : C, $22.46 ; \mathrm{H}, 2.83 ; \mathrm{Br}, 74.71 \%$ ).

HBCD-2 by bromination of TBCD-5. TBCD-5 (7.225 g, $15.0 \mathrm{mmol})$ was dissolved in dichloromethane $(97 \mathrm{ml})$ and acetonitrile $(3 \mathrm{ml})$ and cooled to $2{ }^{\circ} \mathrm{C}$ (ice/water bath) and kept well-stirred. Meanwhile, a solution of bromine ( $c a .2 .6 \mathrm{ml})$ was made up to a concentration of $0.47 \mathrm{M}$ in dichloromethane $(97 \mathrm{ml})$ and acetonitrile $(3 \mathrm{ml})$ and standardised by iodometric titration. The bromine solution $(50.0 \mathrm{ml}, 23.5 \mathrm{mmol})$ was then transferred dropwise by nitrogen pressure through a plastic double-ended needle into the well stirred TBCD-5 solution. The temperature was kept at $2{ }^{\circ} \mathrm{C}$ during the transfer. After the addition was complete, the ice/water bath was removed, and the reaction mixture was allowed to warm to room temperature and then stirred overnight to give an orange solution. The solvent was evaporated in vaccuo at $40{ }^{\circ} \mathrm{C}$ to give a crude orange product $(9.60 \mathrm{~g})$. Quantitative HPLC analysis showed the presence of HBCD-2 (94\%) and HBCD-1 (6\%). The crude product was triturated with dichloromethane to give a creamcoloured solid which was then washed with ethanol to give HBCD-2 (8.50 g, 85\% yield, 95\% purity). Crystallisation from acetonitrile provided pure white crystals of HBCD-2 (7.24 g, $75 \%)$. Mp $170-172{ }^{\circ} \mathrm{C}, \delta_{\mathrm{H}}\left(-50{ }^{\circ} \mathrm{C}, \mathrm{CDCl}_{3}-\mathrm{d}_{8}\right.$-toluene $\left.10: 90\right)$ 3.55-4.11 (m, $\left.4 \mathrm{H}, \mathrm{H}_{\mathrm{a}}, \mathrm{H}_{\mathrm{b}}, \mathrm{H}_{\mathrm{c}}, \mathrm{H}_{\mathrm{d}}\right), 3.19\left(\mathrm{~d}, 1 \mathrm{H}, \mathrm{H}_{\mathrm{e}}\right), 2.76(\mathrm{t}, 1 \mathrm{H}$, $\left.\mathrm{H}_{\mathrm{f}}\right), 2.15-2.32\left(\mathrm{~m}, 2 \mathrm{H}, \mathrm{H}_{\mathrm{g}}, \mathrm{H}_{\mathrm{h}}\right), 1.85-1.97\left(\mathrm{~m}, 2 \mathrm{H}, \mathrm{H}_{\mathrm{i}}, \mathrm{H}_{\mathrm{j}}\right), 1.53$ $\left(\mathrm{m}, 1 \mathrm{H}, \mathrm{H}_{\mathrm{k}}\right), 1.00\left(\mathrm{~m}, 1 \mathrm{H}, \mathrm{H}_{1}\right), 0.88\left(\mathrm{~m}, 1 \mathrm{H}, \mathrm{H}_{\mathrm{m}}\right), 0.65-0.81(\mathrm{~m}$, $\left.2 \mathrm{H}, \mathrm{H}_{\mathrm{n}}, \mathrm{H}_{\mathrm{o}}\right), 0.47\left(\mathrm{~m}, 1 \mathrm{H}, \mathrm{H}_{\mathrm{p}}\right), 0.33\left(\mathrm{td}, 1 \mathrm{H}, \mathrm{H}_{\mathrm{q}}\right)$ and $0.18(\mathrm{t}$, $\left.1 \mathrm{H}, \mathrm{H}_{\mathrm{r}}\right) ; \delta_{\mathrm{H}}\left(-50{ }^{\circ} \mathrm{C}, \mathrm{CDCl}_{3}-\mathrm{d}_{8}\right.$-toluene $\left.90: 10\right) 4.35(\mathrm{~m}, 1 \mathrm{H}$, $\left.\mathrm{H}_{\mathrm{b}}\right), 4.30\left(\mathrm{~m}, 1 \mathrm{H}, \mathrm{H}_{\mathrm{a}}\right), 4.13\left(\mathrm{~d}, 1 \mathrm{H}, \mathrm{H}_{\mathrm{c}}\right), 4.08-4.10\left(\mathrm{~m}, 2 \mathrm{H}, \mathrm{H}_{\mathrm{d}}\right.$, $\left.\mathrm{H}_{\mathrm{e}}\right), 3.60\left(\mathrm{t}, 1 \mathrm{H}, \mathrm{H}_{\mathrm{f}}\right), 2.64\left(\mathrm{~m}, 1 \mathrm{H}, \mathrm{H}_{\mathrm{g}}\right), 2.53\left(\mathrm{~m}, 1 \mathrm{H}, \mathrm{H}_{\mathrm{i}}\right), 2.45$ $\left(\mathrm{m}, 1 \mathrm{H}, \mathrm{H}_{\mathrm{j}}\right), 2.36\left(\mathrm{~m}, 1 \mathrm{H}, \mathrm{H}_{\mathrm{h}}\right), 2.12\left(\mathrm{~m}, 1 \mathrm{H}, \mathrm{H}_{\mathrm{l}}\right), 2.10(\mathrm{~m}, 1 \mathrm{H}$, $\left.\mathrm{H}_{\mathrm{k}}\right), 1.74\left(\mathrm{~m}, 1 \mathrm{H}, \mathrm{H}_{\mathrm{q}}\right), 1.67\left(\mathrm{~m}, 1 \mathrm{H}, \mathrm{H}_{\mathrm{n}}\right), 1.54-1.60(\mathrm{~m}, 2 \mathrm{H}$, $\left.\mathrm{H}_{\mathrm{m}}, \mathrm{H}_{\mathrm{o}}\right)$ and $1.38-1.43\left(\mathrm{~m}, 2 \mathrm{H}, \mathrm{H}_{\mathrm{p}}, \mathrm{H}_{\mathrm{r}}\right) ; \delta_{\mathrm{C}}\left(-50{ }^{\circ} \mathrm{C}, \mathrm{CDCl}_{3}-\right.$ $\mathrm{d}_{8}$-toluene $\left.10: 90\right) 61.3$ (C-5 or C-10), 59.6 (C-10 or C-5), 57.5 (C-1 or C-2), 57.2 (C-2 or C-1), 52.6 (C-9 or C-6), 49.3 (C-6 or C-9), 37.6 (C-4 or C-11), 32.9 (C-7 or C-8), 32.6 (C-3 or C-12), $31.7(\mathrm{C}-12$ or $\mathrm{C}-3), 31.6(\mathrm{C}-8$ or $\mathrm{C}-7)$ and $29.5(\mathrm{C}-11$ or $\mathrm{C}-4) ; \delta_{\mathrm{C}}$ $\left(-50{ }^{\circ} \mathrm{C}, \mathrm{CDCl}_{3}-\mathrm{d}_{8}\right.$-toluene $\left.90: 10\right) 60.8(\mathrm{C}-5$ or $\mathrm{C}-10), 59.1$ (C-10 or C-5), 56.8 (C-1 or C-2), 56.8 (C-2 or C-1), 52.1 (C-9 or C-6), 48.9 (C-6 or C-9), 38.0 (C-4 or C-11), 33.1 (C-7 or C-8), 32.8 (C-3 or C-12), 32.3 (C-12 or C-3), 31.8 (C-8 or C-7) and 29.9 (C-11 or C-4); $m / z$ (EI) $563\left(\mathrm{M}^{+}-{ }^{79} \mathrm{Br},<1 \%\right), 561\left(\mathrm{M}^{+}-\right.$ $\left.{ }^{81} \mathrm{Br},<1\right), 482\left(\mathrm{M}^{+}-{ }^{79} \mathrm{Br}-{ }^{81} \mathrm{Br},<1\right), 403(<1), 401(<1), 321$ (2), 241 (5), 239 (8), 159 (32), 131 (12), 105 (28), 91 (62), 79 (100), 67 (58), 65 (36), 53 (54), 41 (63) and 39 (62) (Found: C, 22.42; $\mathrm{H}, 2.80 ; \mathrm{Br}, 74.79$. Calc. for $\mathrm{C}_{12} \mathrm{H}_{18} \mathrm{Br}_{6}: \mathrm{C}, 22.46 ; \mathrm{H}, 2.83 ; \mathrm{Br}$, $74.71 \%)$.

HBCD-3 by thermal rearrangement of HBCD-1. HBCD-1 $(11.475 \mathrm{~g}, 17.88 \mathrm{mmol})$ in a dry $100 \mathrm{ml}$ round-bottomed flask equipped with a condenser, a magnetic stirrer and a rubber septum was flushed with nitrogen and maintained under a positive nitrogen pressure. The flask was placed in a silicone oil bath regulated with a contact thermometer to $\pm 1{ }^{\circ} \mathrm{C}$. The mixture was heated for $45 \mathrm{~min}$ at $190{ }^{\circ} \mathrm{C}$, then the flask was removed from the oil bath and allowed to cool to room temperature to give a hard black crude product $(11.07 \mathrm{~g})$. Quantitative HPLC analysis showed the presence of HBCD$3(81 \%)$, HBCD-2 (12\%) and HBCD-1 (7\%). The crude product was triturated with a mixture of ethanol and acetonitrile (60 : 40 ) overnight and filtered to give a grey solid ( $9.75 \mathrm{~g}, 85 \%$ yield). The solid was dissolved in acetonitrile and stirred with activated charcoal then filtered and concentrated to give white crystals $(8.50 \mathrm{~g}, 74 \%)$. Mp $179-181{ }^{\circ} \mathrm{C}, \delta_{\mathrm{H}}\left(-25^{\circ} \mathrm{C}, \mathrm{CDCl}_{3}-\mathrm{d}_{8}\right.$-toluene $75: 25) 3.78\left(\mathrm{~d}, 2 \mathrm{H}, \mathrm{H}_{\mathrm{a}}\right), 3.63\left(\mathrm{dd}, 2 \mathrm{H}, \mathrm{H}_{\mathrm{b}}\right), 3.59\left(\mathrm{~d}, 2 \mathrm{H}, \mathrm{H}_{\mathrm{c}}\right)$, $2.20\left(\mathrm{td}, 2 \mathrm{H}, \mathrm{H}_{\mathrm{d}}\right), 2.07\left(\mathrm{t}, 2 \mathrm{H}, \mathrm{H}_{\mathrm{e}}\right), 1.75\left(\mathrm{~m}, 2 \mathrm{H}, \mathrm{H}_{\mathrm{f}}\right), 1.59$ $\left(\mathrm{m}, 2 \mathrm{H}, \mathrm{H}_{\mathrm{g}}\right), 1.40\left(\mathrm{t}, 2 \mathrm{H}, \mathrm{H}_{\mathrm{h}}\right)$ and $1.09\left(\mathrm{q}, 2 \mathrm{H}, \mathrm{H}_{\mathrm{i}}\right) ; \delta_{\mathrm{C}}\left(-25^{\circ} \mathrm{C}\right.$, $\mathrm{CDCl}_{3}-\mathrm{d}_{8}$-toluene $\left.75: 25\right) 57.8(\mathrm{C}-6), 52.1(\mathrm{C}-2), 50.4(\mathrm{C}-5), 34.6$ (C-7), 33.5 (C-3) and 32.2 (C-4), $m / z$ (EI) $563\left(\mathrm{M}^{+}-{ }^{79} \mathrm{Br},<1 \%\right.$ ), $561\left(\mathrm{M}^{+}-{ }^{81} \mathrm{Br},<1\right), 482\left(\mathrm{M}^{+}-{ }^{79} \mathrm{Br}-{ }^{81} \mathrm{Br},<1\right), 403(<1), 401$ (<1), 321 (3), 319 (2), 241 (8), 239 (10), 159 (35), 131 (12), 105 (22), 91 (52), 79 (86), 67 (65), 65 (31), 53 (48), 41 (100) and 39 (69) (Found: C, 24.35; H, 2.99; Br, 72.66. Calc. for $\mathrm{C}_{12} \mathrm{H}_{18} \mathrm{Br}_{6}+$ $0.65 \mathrm{MeCN}$ : C, 23.87; H, 2.98; Br, 71.79\%).

TBCD-4 by thermal rearrangement of TBCD-5. TBCD-5 $(11.75 \mathrm{~g}, 22.00 \mathrm{mmol})$ in a dry $100 \mathrm{ml}$ round-bottomed flask equipped with a condenser, a magnetic stirrer and a rubber septum was flushed with nitrogen and maintained under a positive nitrogen pressure. The flask was placed in a silicone oil bath regulated with a contact thermometer to $\pm 1{ }^{\circ} \mathrm{C}$. The mixture was heated for $60 \mathrm{~min}$ at $180{ }^{\circ} \mathrm{C}$, then the flask was removed from the oil bath and allowed to cool to room temperature to give a dark, transparent, crude product (11.64 g). The HPLC peak area analysis showed the presence of TBCD-4 $(\sim 68 \%)$ and TBCD-5 $(\sim 32 \%)$. The crude product was triturated with a mixture of ethanol and acetonitrile $(60: 40)$ overnight to give a brown solid. The solid was dissolved in acetonitrile and then stirred with activated charcoal, filtered and concentrated to give a light brown solid, TBCD-4 (10.81 g, 92\% yield, 52\% purity). Consecutive recrystallisation from a mixture of ethanol and dichloromethane $(60: 40)$ provided pure white crystals of TBCD-4 $(2.5 \mathrm{~g}, 21 \%)$. Mp $125-127^{\circ} \mathrm{C}, \delta_{\mathrm{H}}\left(25^{\circ} \mathrm{C}, \mathrm{CDCl}_{3}\right) 5.63$ $(\mathrm{m}, 1 \mathrm{H}, \mathrm{CH}=\mathrm{CH}), 5.46(\mathrm{~m}, 1 \mathrm{H}, \mathrm{CH}=\mathrm{CH}), 4.51(\mathrm{~m}, 1 \mathrm{H}, \mathrm{CH}-$ $\mathrm{Br}), 4.43(\mathrm{~m}, 1 \mathrm{H}, \mathrm{CH}-\mathrm{Br}), 4.18(\mathrm{~m}, 1 \mathrm{H}, \mathrm{CH}-\mathrm{Br}), 4.18(\mathrm{~m}, 1 \mathrm{H}$, $\mathrm{CH}-\mathrm{Br}$ ) and $1.89-2.52$ (br m, $\left.12 \mathrm{H}, 6 \times \mathrm{CH}_{2}\right) ; \delta_{\mathrm{C}}\left(25^{\circ} \mathrm{C}, \mathrm{CDCl}_{3}\right)$ $132.9,131.2(2 \times \mathrm{CH}=\mathrm{C}), 61.4,52.8$ (double intensity), 51.0 $(4 \times \mathrm{CHBr})$ and 36.8, 35.5, 33.8, 31.4, 30.4, $30.1\left(6 \times \mathrm{CH}_{2}\right)$; $m / z$ (EI) $482\left(\mathrm{M}^{+}\left({ }^{79} \mathrm{Br}_{2}{ }^{81} \mathrm{Br}_{2}\right),<1 \%\right), 403\left(\mathrm{M}^{+}-{ }^{79} \mathrm{Br},<1\right), 401$ $\left(\mathrm{M}^{+}-{ }^{81} \mathrm{Br},<1\right), 321\left(\mathrm{M}^{+}-\mathrm{H}-{ }^{79} \mathrm{Br}-{ }^{81} \mathrm{Br}, 3\right), 241$ (11), 239 (11), 160 (10), 159 (52), 131 (14), 119 (18), 105 (25), 93 (29), 91 (52), 81 (46), 79 (92), 77 (35), 67 (100), 65 (38), 53 (63) and 41 (85) (Found: $\mathrm{C}, 29.97 ; \mathrm{H}, 3.79 ; \mathrm{Br}, 66.24$. Calc. for $\mathrm{C}_{12} \mathrm{H}_{18} \mathrm{Br}_{4}$ : C, $29.91 ; \mathrm{H}, 3.76 ; \mathrm{Br}, 66.33 \%)$.

TBCD-5 by bromination of CDT. A solution of CDT (4.47 g, $27.5 \mathrm{mmol})$ in a mixture of ethanol $(0.5 \mathrm{ml})$ and dichloromethane $(49.5 \mathrm{ml})$ was cooled to $-78{ }^{\circ} \mathrm{C}$ in a dry-ice/acetone bath and kept well-stirred. Meanwhile, a solution of bromine $(c a .5 .2 \mathrm{ml})$ was made up to a concentration of $0.50 \mathrm{M}$ in ethanol $(2 \mathrm{ml})$ and dichloromethane $(198 \mathrm{ml})$, and standardised by iodometric titration. The bromine solution $(106 \mathrm{ml}, 53 \mathrm{mmol})$ was then transferred dropwise by nitrogen pressure through a plastic double-ended needle into the well-stirred CDT solution. The temperature was kept at $-78{ }^{\circ} \mathrm{C}$ during the transfer. After the addition was complete, the reaction mixture was stirred for $1 \mathrm{~h}$ at $-78^{\circ} \mathrm{C}$, allowed to warm to room temperature and then stirred for a further $2 \mathrm{~h}$ to give an orange solution. The solvent was then evaporated in vacuo at $40^{\circ} \mathrm{C}$ to give a crude cream-coloured solid $(13.27 \mathrm{~g})$. The HPLC peak area analysis showed the presence of TBCD-5 (94\%) and an unknown (6\%). The crude solid was then washed with ethanol to give TBCD-5 (11.28 g, 85\% yield, 99\% purity) as a white solid; crystallisation from dichloromethane provided pure white crystals of TBCD-5 $(10.8 \mathrm{~g}, 80 \%)$. Mp $167-$ $169^{\circ} \mathrm{C}, \delta_{\mathrm{H}}\left(-50{ }^{\circ} \mathrm{C}, \mathrm{CDCl}_{3}\right)$ major conformation: $4.99(\mathrm{~s}, 2 \mathrm{H})$, $4.58(\mathrm{~m}, 1 \mathrm{H}), 4.10(\mathrm{~m}, 1 \mathrm{H}), 3.69(\mathrm{~d}, 1 \mathrm{H}), 3.56(\mathrm{~m}, 1 \mathrm{H})$ and $1.48-2.13(\mathrm{~m}, 12 \mathrm{H})$; minor conformation: $5.16(\mathrm{~s}, 2 \mathrm{H}), 4.58(\mathrm{~m}$, $1 \mathrm{H}, 4.10(\mathrm{~m}, 1 \mathrm{H}), 3.56(\mathrm{~m}, 1 \mathrm{H}), 3.43(\mathrm{~d}, 1 \mathrm{H})$ and $1.50-2.10$ $(\mathrm{m}, 12 \mathrm{H}) ; \delta_{\mathrm{C}}\left(-50{ }^{\circ} \mathrm{C}, \mathrm{CDCl}_{3}\right) 132.9,129.3(2 \times \mathrm{CH}=\mathrm{C}), 63.0$, 58.5, 54.0, $53.5(4 \times \mathrm{CHBr}), 2 \times 35.0,33.8,33.7,32.2,30.3(6 \times$ 
$\left.\mathrm{CH}_{2}\right) ; m / z$ (EI) $482\left(\mathrm{M}^{+}\left({ }^{79} \mathrm{Br}_{2}{ }^{81} \mathrm{Br}_{2}\right),<1 \%\right), 403\left(\mathrm{M}^{+}-{ }^{79} \mathrm{Br},<1\right)$, $401\left(\mathrm{M}^{+}-{ }^{81} \mathrm{Br},<1\right), 321\left(\mathrm{M}^{+}-\mathrm{H}-{ }^{79} \mathrm{Br}-{ }^{81} \mathrm{Br}, 5\right), 241$ (18), 239 (18), 160 (14), 159 (63), 131 (15), 119 (18), 105 (22), 93 (26), 91 (45), 81 (37), 79 (67), 77 (25), 67 (100), 65 (31), 53 (41) and 41 (48) (Found: C, 29.79; H, 3.74; Br, 66.48. Calc. for $\mathrm{C}_{12} \mathrm{H}_{18} \mathrm{Br}_{4}$ : C, $29.91 ; \mathrm{H}, 3.76 ; \mathrm{Br}, 66.33 \%)$.

TBCD-6 by thermal rearrangement of TBCD-7. TBCD-7 $(13.767 \mathrm{~g}, 28.58 \mathrm{mmol})$ in a dry $100 \mathrm{ml}$ round-bottomed flask equipped with a condenser, a magnetic stirrer and a rubber septum was flushed with nitrogen and maintained under a positive nitrogen pressure. The flask was placed in a silicone oil bath regulated with a contact thermometer to $\pm 1{ }^{\circ} \mathrm{C}$. The mixture was heated for $40 \mathrm{~min}$ at $160{ }^{\circ} \mathrm{C}$, then the flask was removed from the oil bath and allowed to cool to room temperature to give a light yellow, transparent, crude product $(13.76 \mathrm{~g})$. The HPLC peak area analysis showed the presence of TBCD-6 (46\%), TBCD-7 (48\%), and two unknowns (5\%). The crude product was triturated with a mixture of ethanol and acetonitrile $(60: 40)$ overnight and filtered to give a white solid ( $12.10 \mathrm{~g}, 88 \%$ yield) with composition similar to the crude material. The TBCD mixture was washed with ethanol, which removed the unknowns to leave a mixture of TBCD-6 and TBCD-7 (9.706 g, 71\% yield). This material was extracted with a mixture of ethanol and dichloromethane $(80: 20)$, so as to leave a little undissolved solid, which was mainly TBCD-7. The mixture was filtered and the filtrate was concentrated to give a solid richer in TBCD-6. The extraction process was repeated several times until the solid obtained by evaporation showed a peak area ratio of $c a$. $66: 34$ (TBCD-6 : TBCD-7). The solid $(5.82 \mathrm{~g})$ was then repeatedly recrystallised from acetonitrile until the solid obtained was pure TBCD-6 $(2.11 \mathrm{~g})$. Mp $118-121{ }^{\circ} \mathrm{C}$, $\delta_{\mathrm{H}}\left(-25^{\circ} \mathrm{C}, \mathrm{CDCl}_{3}-\mathrm{d}_{8}\right.$-toluene $\left.25: 75\right) 5.23\left(\mathrm{~m}, 2 \mathrm{H}, \mathrm{H}_{\mathrm{a}}\right), 4.11$ $\left(\mathrm{m}, 2 \mathrm{H}, \mathrm{H}_{\mathrm{b}}\right), 4.05\left(\mathrm{~m}, 2 \mathrm{H}, \mathrm{H}_{\mathrm{c}}\right), 1.98\left(\mathrm{~m}, 4 \mathrm{H}, \mathrm{H}_{\mathrm{d}}, \mathrm{H}_{\mathrm{e}}\right), 1.75(\mathrm{~m}$, $\left.2 \mathrm{H}, \mathrm{H}_{\mathrm{f}}\right), 1.20\left(\mathrm{~m}, 2 \mathrm{H}, \mathrm{H}_{\mathrm{g}}\right), 1.05\left(\mathrm{~m}, 2 \mathrm{H}, \mathrm{H}_{\mathrm{h}}\right)$ and $1.00(\mathrm{~m}, 2 \mathrm{H}$, $\left.\mathrm{H}_{\mathrm{i}}\right) ; \delta_{\mathrm{C}}\left(-25^{\circ} \mathrm{C}, \mathrm{CDCl}_{3}-\mathrm{d}_{8}\right.$-toluene $\left.25: 75\right) 128.7,61.5,51.0$, 33.7, 39.2 and 24.8; $\mathrm{m} / z$ (EI) $482\left(\mathrm{M}^{+}\left({ }^{79} \mathrm{Br}_{2}{ }^{81} \mathrm{Br}_{2}\right),<1 \%\right), 403$ $\left(\mathrm{M}^{+}-{ }^{79} \mathrm{Br}, 3.5\right), 401\left(\mathrm{M}^{+}-{ }^{81} \mathrm{Br}, 3.5\right), 321\left(\mathrm{M}^{+}-\mathrm{H}-{ }^{79} \mathrm{Br}-\right.$ $\left.{ }^{81} \mathrm{Br}, 5\right), 241$ (10), 239 (10), 160 (12), 159 (49), 131 (15), 119 (20), 105 (25), 93 (30), 91 (55), 81 (40), 79 (95), 77 (40), 67 (90), 65 (40), 53 (65) and 41 (100) (Found C, 29.80; H, 3.85; Br, 66.36. Calc. for $\mathrm{C}_{12} \mathrm{H}_{18} \mathrm{Br}_{4}$ : C, 29.91; H, 3.76; $\mathrm{Br}, 66.33 \%$ ).

TBCD-7 by bromination of CDT. A solution of CDT $(10.71 \mathrm{~g}, 66.0 \mathrm{mmol})$ in ethanol $(96 \mathrm{ml})$ and dichloromethane (24 ml) was cooled to $-78{ }^{\circ} \mathrm{C}$ in an dry-ice/acetone bath while maintaining vigorous stirring. Meanwhile, a solution of bromine ( $c a .12 .9 \mathrm{ml}$ ) was made up to a concentration of $0.44 \mathrm{M}$ in ethanol $(400 \mathrm{ml})$ and dichloromethane $(100 \mathrm{ml})$, and standardised by iodometric titration. The bromine solution (431 $\mathrm{ml}, 190 \mathrm{mmol}$ ) was then transferred dropwise by use of nitrogen pressure through a plastic double-ended needle into the well-stirred CDT solution. The temperature was kept at $-78^{\circ} \mathrm{C}$ during this transfer. After the addition was complete, the reaction mixture was stirred for $1 \mathrm{~h}$ at $-78{ }^{\circ} \mathrm{C}$ and then allowed to warm to room temperature. The mixture was then stirred for a further $2 \mathrm{~h}$ to give an orange solution. The solvent was evaporated in vacuo at $40^{\circ} \mathrm{C}$ to give a crude cream-coloured solid (31.78 g). Quantitative HPLC analysis showed the presence of TBCD-7 (72\%), TBCD-5 (10\%) and CDT (18\%). The crude solid was then washed with ethanol to give TBCD-7 (20.34 g, $64 \%$ yield, $91 \%$ purity) as a white solid. Recrystallisation from a mixture of ethanol and dichloromethane $(60: 40)$ provided pure white crystals of TBCD-7 (15.16 g, 48\%). Mp 129-131 ${ }^{\circ} \mathrm{C}$, $\delta_{\mathrm{H}}\left(50{ }^{\circ} \mathrm{C}, \mathrm{CDCl}_{3}\right) 5.53(\mathrm{~m}, 2 \mathrm{H}, \mathrm{CH}=\mathrm{CH}), 4.49($ br s, $2 \mathrm{H}$, $\mathrm{CHBr}$ ), 4.32 (br s, $2 \mathrm{H}, \mathrm{CHBr}$ ) and 2.13-2.41 (br m, $12 \mathrm{H}, \mathrm{CH}_{2}$ ); $\delta_{\mathrm{C}}\left(50{ }^{\circ} \mathrm{C}, \mathrm{CDCl}_{3}\right) 129.2(\mathrm{CH}=\mathrm{CH}), 55.5(2 \times \mathrm{CHBr}), 36.2,33.6$ and $25.0\left(3 \times \mathrm{CH}_{2}\right) ; \mathrm{m} / z(\mathrm{EI}) 482\left(\mathrm{M}^{+}\left({ }^{79} \mathrm{Br}_{2}{ }^{81} \mathrm{Br}_{2}\right), 1 \%\right), 403$ $\left(\mathrm{M}^{+}-{ }^{79} \mathrm{Br}, 2\right), 401\left(\mathrm{M}^{+}-{ }^{81} \mathrm{Br}, 2\right), 323\left(\mathrm{M}^{+}-\mathrm{H}-2 \times{ }^{79} \mathrm{Br}, 3\right)$, $321\left(\mathrm{M}^{+}-\mathrm{H}-{ }^{79} \mathrm{Br}-{ }^{81} \mathrm{Br}, 6\right), 319\left(\mathrm{M}^{+}-\mathrm{H}-2 \times{ }^{81} \mathrm{Br}, 3\right), 241$ (12), 239 (12), 160 (12), 159 (53), 131 (10), 119 (18), 105 (22),
93 (28), 91 (51), 81 (40), 79 (79), 77 (31), 67 (100), 65 (33), 53 (52) and 41 (74) (Found: C, 29.98; H, 3.81; Br, 66.22. Calc. for $\mathrm{C}_{12} \mathrm{H}_{18} \mathrm{Br}_{4}$ : C, 29.91; H, 3.76; Br, 66.33\%).

DBCD-8 by bromination of CDT. A solution of CDT $(1.785 \mathrm{~g}, 11.00 \mathrm{mmol})$ in ethanol $(12 \mathrm{ml})$ and dichloromethane $(8 \mathrm{ml})$ was cooled to $-78{ }^{\circ} \mathrm{C}$ in a dry-ice/acetone bath whilst maintaining vigorous stirring. Meanwhile, a solution of bromine (ca. $1.3 \mathrm{ml}$ ) was made up to a concentration of $0.46 \mathrm{M}$ in ethanol $(30 \mathrm{ml})$ and dichloromethane $(20 \mathrm{ml})$ and standardised by iodometric titration. The bromine solution $(26 \mathrm{ml}, 11.96 \mathrm{mmol})$ was then transferred dropwise by use of nitrogen pressure through a plastic double-ended needle into the well-stirred CDT solution. The temperature was kept at $-78{ }^{\circ} \mathrm{C}$ during this transfer. After the addition was complete, the reaction mixture was stirred for $1 \mathrm{~h}$ at $-78^{\circ} \mathrm{C}$, allowed to warm to room temperature and then stirred for a further $2 \mathrm{~h}$ to give an orange solution. The solvent was then evaporated in vacuo at $40{ }^{\circ} \mathrm{C}$ to give crude DBCD-8 as an oil. The HPLC peak area analysis showed the presence of DBCD-8 (87\%), TBCD-5 (3\%) and CDT $(10 \%)$. The crude product was triturated with acetonitrile, filtered and washed with acetonitrile to give DBCD-8 (2.76 g, $78 \%$ yield) as a brown solid, which was substantially pure by HPLC. Crystallisation from acetonitrile provided pure white crystals of DBCD-8 in $74 \%$ yield. Mp $58-59{ }^{\circ} \mathrm{C} ; \delta_{\mathrm{H}}\left(-20{ }^{\circ} \mathrm{C}\right.$, $\left.\mathrm{CDCl}_{3}\right)$ 5.39-5.56 (m, $\left.4 \mathrm{H}, \mathrm{CH}=\mathrm{CH}\right), 4.53-4.5(\mathrm{~m}, 2 \mathrm{H}, \mathrm{CHBr})$ and $1.83-2.48\left(\mathrm{~m}, 12 \mathrm{H}, \mathrm{CH}_{2}\right) ; \delta_{\mathrm{C}}\left(-20^{\circ} \mathrm{C}, \mathrm{CDCl}_{3}\right) 128.2,128.4$, 129.1, $131.1(4 \times \mathrm{CH}=\mathrm{C}), 53.6,60.7(2 \times \mathrm{CHBr}), 36.3,32.9$, 31.1, 30.3, 27.9 and 26.6 $\left(6 \times \mathrm{CH}_{2}\right) ; \mathrm{m} / z$ (EI) $324\left(\mathrm{M}^{+}\left({ }^{81} \mathrm{Br}^{81} \mathrm{Br}\right)\right.$, 0.5), $322\left(\mathrm{M}^{+79} \mathrm{Br}^{81} \mathrm{Br}, 1\right), 320\left(\mathrm{M}^{+}\left({ }^{79} \mathrm{Br}^{79} \mathrm{Br}\right), 0.5\right), 243\left(\mathrm{M}^{+}-{ }^{79} \mathrm{Br}\right.$, 5), $241\left(\mathrm{M}^{+}-{ }^{81} \mathrm{Br}, 5\right), 162$ (14), 161 (100), 133 (31), 119 (32), 107 (42), 105 (25), 93 (33), 91 (51), 81 (6) and 79 (14) (Found: C, 44.66; $\mathrm{H}, 5.80 ; \mathrm{Br}$, 49.55. Calc. for $\mathrm{C}_{12} \mathrm{H}_{18} \mathrm{Br}_{2}$ : C, 44.75; H, 5.63; $\mathrm{Br}, 49.62 \%)$.

DBCD-9 by debromination of TBCD-5 with zinc. TBCD$5(7.32 \mathrm{~g}, 15.20 \mathrm{mmol})$ was dissolved in ethanol $(600 \mathrm{ml})$ at $90{ }^{\circ} \mathrm{C}$. The TBCD-5 solution was transferred dropwise by nitrogen pressure through a double-ended needle into a vigorously stirred mixture of zinc powder $(0.995 \mathrm{~g}, 15.22 \mathrm{mmol})$ in ethanol $(100 \mathrm{ml})$ over a period of $10 \mathrm{~min}$. The TBCD solution was kept at $90{ }^{\circ} \mathrm{C}$ during this transfer. After the addition was complete, the reaction mixture was allowed to cool to room temperature, stirred for an additional $48 \mathrm{~h}$, filtered and concentrated. The concentrate was diluted with water and extracted twice with pentane to give an oil which was dissolved in hot ethanol and allowed to crystallise to provide pure white crystals of DBCD-9 $(0.3 \mathrm{~g})$. Mp $55^{\circ} \mathrm{C} ; \delta_{\mathrm{H}}\left(-70{ }^{\circ} \mathrm{C}, \mathrm{CDCl}_{3}-\mathrm{d}_{8}-\right.$ toluene $50: 50) 4.66\left(\mathrm{~m}, 4 \mathrm{H}, \mathrm{H}_{\mathrm{a}}\right.$ and $\left.\mathrm{H}_{\mathrm{b}}\right), 3.90\left(\mathrm{dd}, 2 \mathrm{H}, \mathrm{H}_{\mathrm{c}}\right)$, $2.20\left(\mathrm{~m}, 2 \mathrm{H}, \mathrm{H}_{\mathrm{d}}\right), 2.03\left(\mathrm{~m}, 2 \mathrm{H}, \mathrm{H}_{\mathrm{e}}\right), 1.95\left(\mathrm{~m}, 4 \mathrm{H}, \mathrm{H}_{\mathrm{f}}\right.$ and $\left.\mathrm{H}_{\mathrm{g}}\right)$, $1.83\left(\mathrm{~m}, 2 \mathrm{H}, \mathrm{H}_{\mathrm{h}}\right)$ and $1.65\left(\mathrm{~m}, 2 \mathrm{H}, \mathrm{H}_{\mathrm{i}}\right) ; \delta_{\mathrm{H}}\left(-70{ }^{\circ} \mathrm{C}, \mathrm{d}_{8}\right.$-toluene $)$ $4.53\left(\mathrm{~m}, 2 \mathrm{H}, \mathrm{H}_{\mathrm{a}}\right), 4.44\left(\mathrm{~m}, 2 \mathrm{H}, \mathrm{H}_{\mathrm{b}}\right), 3.98\left(\mathrm{dd}, 2 \mathrm{H}, \mathrm{H}_{\mathrm{c}}\right), 2.49(\mathrm{t}$, $\left.2 \mathrm{H}, \mathrm{H}_{\mathrm{d}}\right), 2.1-2.0\left(\mathrm{~m}, 4 \mathrm{H}, \mathrm{H}_{\mathrm{e}}\right.$ and $\left.\mathrm{H}_{\mathrm{g}}\right), 2.0-1.9\left(\mathrm{br}, 4 \mathrm{H}, \mathrm{H}_{\mathrm{f}}\right.$ and $\left.\mathrm{H}_{\mathrm{h}}\right)$ and $1.63\left(\mathrm{~m}, 2 \mathrm{H}, \mathrm{H}_{\mathrm{i}}\right) ; \delta_{\mathrm{C}}\left(-70{ }^{\circ} \mathrm{C}, \mathrm{d}_{8}\right.$-toluene) $128.8,134.0$, 55.4, 38.0, 32.2 and 30.7; $\mathrm{m} / \mathrm{z}$ (EI) $322\left(\mathrm{M}^{+}\left({ }^{79} \mathrm{Br}^{81} \mathrm{Br}\right),<1\right), 243$ $\left(\mathrm{M}^{+}-{ }^{79} \mathrm{Br}, 2\right), 241\left(\mathrm{M}^{+}-{ }^{81} \mathrm{Br}, 2\right), 162$ (7), 161 (50), 133 (14), 119 (16), 107 (24), 105 (14), 93 (18), 91 (34), 79 (78), 77 (27), 67 (83), 65 (27), 54 (100), 53 (46), 41 (69) and 39 (65) (Found: C, 44.57; $\mathrm{H}, 5.78 ; \mathrm{Br}$, 49.66. Calc. for $\mathrm{C}_{12} \mathrm{H}_{18} \mathrm{Br}_{2}$ : C, 44.75; H, 5.63; $\mathrm{Br}, 49.62 \%)$.

\section{General procedure for analytical scale reactions}

To the stirred substrate in the appropriate solvent at the temperature given was added a standardised solution of bromine in the appropriate solvent which was also at a set temperature before the addition, though not necessarily at the same temperature. After the appropriate time at the desired temperature the solvent was removed, the crude product was weighed and the sample was analysed by HPLC. The analytical results are given in the appropriate tables. 


\section{Acknowledgements}

We thank Associated Octel (now Great Lakes Chemicals), Ethyl Corporation (now Albemarle Corporation) and the University of Wales Swansea for financial support, Drs. P. F. Ranken, P. Ashorth and J. C. Chetland for useful discussion, the EPSRC Mass Spectrometry Centre at Swansea for mass spectra and the EPSRC National Crystallography Service for the crystal structures. We also thank the EPSRC, the Higher Education Funding Council for Wales (ELWa-HEFCW) and the University of Wales Swansea for grants that enabled the purchase and upgrading of NMR equipment used in the course of this work. G. A. El-Hiti thanks the Royal Society of Chemistry for an international author grant.

\section{References}

1 Kirk-Othmer Encyclopedia of Chemical Technology, 3rd edn., John Wiley and Sons, New York, 1980, vol. 10, p. 373.

2 Kirk-Othmer Encyclopedia of Chemical Technology, 4th edn., John Wiley and Sons, New York, 1993, vol. 10, p. 930.

3 Kirk-Othmer Encyclopedia of Chemical Technology, 4th edn., John Wiley and Sons, New York, 1993, vol. 10, p. 954.

4 B. M. Valange, S. E. Calewarts, G. A. Bonner, F. A. Pettigrew and R. A. Schleifstein, in Flame Retard. 90, Proc., British Plastics Federation, Elsevier, London, 1990, pp. 67-77.

5 (a) E. R. Larsen and E. L. Ecker, J. Fire Sci., 1986, 4, 261; (b) E. R. Larsen and E. L. Ecker, J. Fire Sci., 1988, 6, 139.

6 M. Englert, P. Allemand, P. Ashworth, J. C. Chetland and T. P. Fidelle, Jr., in Advances In Organobromine Chemistry I, ed. J.-R. Desmurs and B. Gérard, Elsevier, Amsterdam, 1991, pp. 245284.

7 (a) K. Smith, in Advances In Organobromine Chemistry I, ed. J.-R. Desmurs and B. Gérard, Elsevier, Amsterdam, 1991, pp. 1721; (b) A. Groweiss, J. Hermolin, and I. Goldberg, in Advances In Organobromine Chemistry I, ed. J.-R. Desmurs and B. Gérard, Elsevier, Amsterdam, 1991, pp. 61-67.
8 (a) T. Matsuba and K. Kawabata, Jpn Pat. 04,338,343, 1992 (Chem. Abstr., 1993, 118: 233536z; (b) T. Matsuba and K. Kawabata, Jpn Pat. 04,338,344, 1992 (Chem. Abstr., 1993, 118, 168743y; (c) T. Matsuba and K. Kawabata, Jpn Pat. 04,338,345, 1992, (Chem. Abstr., 1993, 118, 168744z).

9 D. D. Thompson, Fr. Pat. 1,553,410, 1969 (Chem. Abstr., 1970, 72, 12218b).

10 R. J. Fessenden and J. S. Fessenden, Organic Chemistry, 2nd edn., Willard Grant, Boston, 1982, p. 402.

11 S. N. Ege, Organic Chemistry, 4th edn., Houghton-Mifflin, Boston, 1999, pp. 296-304.

12 J. E. Dubois and F. Garnier, J. Chem. Soc., Chem. Commun., 1968, 241.

13 K. Yates and W. V. Wright, Tetrahedron Lett., 1965, 6, 1927.

14 M. Peled, R. Scharia and D. Sondack, in Advances In Organobromine Chemistry II, ed. J.-R. Desmurs, B. Gérard and M. J. Goldstein, Elsevier, Amsterdam, 1995, pp. 92-99.

15 P. L. Barili, G. Bellucci, G. Berti, F. Marioni, A. Marsili and I Morelli, J. Chem. Soc., Perkin Trans. 2, 1972, 58.

16 D. H. R. Barton, H. MacGrillen and P. D. Magnus, J. Chem. Soc., Perkin Trans. 1, 1972, 1584.

17 G. Bellucci, A. Marsili, E. Mastrorilli, I. Morelli and V. Scartoni, J. Chem. Soc., Perkin Trans. 2, 1974, 201

18 C. A. Grob and S. Winstein, Helv. Chim. Acta, 1952, 35, 782.

19 J. F. King and R. G. Pews, Can. J. Chem., 1965, 43, 847.

20 J. Sicher, M. Havel and M. Svoboda, Tetrahedron Lett., 1968, 9, 4269.

21 C. L. Stevens and J. A. Valicenti, J. Am. Chem. Soc., 1965, 87, 838.

22 W. G. Young, Z. Jasaitis and L. Levanas, J. Am. Chem. Soc., 1937, 59, 403.

23 W. M. Schubert, B. S. Rabinovitch, N. R. Larson and V. A. Sims, J. Am. Chem. Soc., 1952, 74, 4590.

24 W. G. Young and S. Winstein, J. Am. Chem. Soc., 1936, 58, 102.

25 H. O. House and R. S. Ro, J. Am. Chem. Soc., 1958, 80, 182.

26 M. Gordon and J. V. Hay, J. Org. Chem., 1968, 33, 427.

27 T. Matsuba, K. Kawabata, M. Kubo, Y. Todia and T. Sera, Toso Kenkyu Hokoku, 1991, 35, 57, (Chem. Abstr., 1992, 116, 21969b).

28 D. D. Perrin and W. L. F. Armarego, Purification of Laboratory Chemicals, 3rd edn., Pergamon, Oxford, 1988. 